\title{
SOBRE LA DEFINICIÓN DE TRAGEDIA
}

\section{ON THE DEFINTION OF TRAGEDY}

\author{
Magdalena Cueto Pérez
}

Universidad de Oviedo

\section{ABSTRACT}

This article deals with the study of Greek tragedy based on Aristotle's theory. It examines the requirements that the Poetics establishes for the composition of the fable, taking into account that the characters and thoughts of the characters are subordinated to it, as well as their involvement in the tragic effect. From Aristotelian axiology we deduce the presence in Poetics of a theory of entertainment, linked to catharsis, compatible with the aesthetic value of the work, but not comparable to it.

Key words: Aristóteles, Poética, tragedy, vicissitudes, anagnorisis

\section{RESUMEN}

Este artículo aborda el estudio de la tragedia griega a partir de la teoría de Aristóteles. En él se examinan los requisitos que la Poética establece para la composición de la fábula, teniendo en cuenta que a ella se supeditan los caracteres y pensamientos de los personajes, así como su implicación en el efecto trágico. De la axiología aristotélica deducimos la presencia en la Poética de una teoría del entretenimiento, vinculada a la catarsis, compatible con el valor 
estético de la obra, pero no equiparable al mismo.

Palabras clave: Aristóteles, Poética, tragedia, peropecia, anagnórisis

Fecha de recepción: 25 de octubre de 2021.

Fecha de aceptación: 11 de noviembre de 2021.

Cómo citar: Cueto Pérez, Magdalena (2021): «Sobre la definición de tragedia», en Actio Nova: Revista de Teoría de la Literatura y Literatura Comparada, 5: 285-329.

DOI: https://doi.org/10.15366/actionova2021.5.013 
La definición aristotélica de la tragedia se ofrece en el capítulo sexto de la Poética (6, 49b24-31) en función de los criterios que, según el autor (I, 47a-14-19), permiten establecer diferencias entre la poesía y otras artes miméticas (el medio de imitación), y entre los diferentes tipos de poesía (modo de imitación y objeto imitado) ${ }^{1}$. El medio de imitación es el lenguaje sazonado [la palabra con ritmo, armonía y canto], separada cada una de las especies [de aderezos] en las distintas partes, es decir, el que combina las partes recitadas con las partes cantadas; el objeto imitado es una acción esforzada [spoudaias] y completa, de cierta amplitud (mimesis de los mejores, como la epopeya), y el modo de imitación es el que corresponde a los géneros dramáticos, en los que las palabras y acciones de los personajes se ofrecen directamente, sin mediación narrativa (actuando los personajes y no mediante narración). Aunque más adelante volveré sobre ello, quiero señalar desde ahora que la «actuación directa» no ha de entenderse en el contexto aristotélico únicamente como representación teatral o presencia de los actores en escena, sino también como modalidad específica de dicción ${ }^{2}$, la más apta para que la acción se muestre como un proceso in fieri, en su desarrollo (incluso cuando se trata de la construcción de una idea, como sucede en los diálogos platónicos y, en general, en los diálogos anatrépticos).

A esta definición, añade Aristóteles una brevísima y controvertida referencia al efecto específico de la tragedia, la catarsis: «mediante la compasión [eleos] y el temor [fobos], [la tragedia] lleva a cabo la purgación de tales afecciones». Tales afecciones son la compasión (no la misericordia) y el temor (no el horror), y no cualquier tipo de afección, como pretendieron numerosas exégesis del texto, y en particular las interpretaciones cristianas de la purga trágica de las pasiones contrarias a la virtud, como las de Vicenzo Maggi (1550) o Escalígero (1561), retomadas por los comentaristas franceses del XVII. No voy a examinar aquí las diferentes teorías que han suscitado el término y el concepto (lo ha hecho, por

\footnotetext{
${ }^{1}$ Hemos tenido en cuenta las ediciones que siguen: Poética, ed. bilingüe de J. Alsina, Barcelona, Bosch, 1977; Aristotle's Poetics,con comentarios y glosas de Hipócrates, traducción de G. Apostle, E. Dobbs, M. Parslow, Iowa, Grinnell, 1990; Aristotle's theory of poetry and fine art, traducción y comentarios de S.H. Butcher, introducción de J. Gassner, Nueva York, Dover, 1951; Poética, traducción de A. J. Capelleti, Caracas, Monte Ávila, 1990; Aristotle, on the art of poetry, traducción de L. Cooper, Ithaca, Cornell University Press, 1947; La Poétique, traducción y notas de R. Dupont-Roc et J. Lallot, con prefacio de Tz. Todorov, Paris, Seuil, 1980; Aristotle's Poetics the argument, traducción y comentarios de F.G. Elsen, Leiden, E.J. Brill, 1957; Poética, traducción de J. D. García Bacca, UNAM, 2000; La Poética de Aristóteles, edición trilingüe, traducción y comentarios de V. García, Yebra, Madrid, Gredos, 1974; Arte Poética, traducción de Anibal González, Madrid, Taurus, 1987; Aristotle's Poetics, traducción, notas y comentarios de D. W. Lucas, Oxford, University Press, 1968; Poética, traducción de A. Llanos, Buenos Aires, Leviatán, 1980. Las citas, salvo otra indicación explícita, corresponden a la edición de Valentín García Yebra (1974).

${ }^{2}$ En el sentido de Genette (1979).
} 
ejemplo, Bobes $)^{3}$, pero sí quiero indicar que la catarsis desliza la teoría poética aristotélica del lado del entretenimiento, en el sentido de que orienta la composición de la trama al efecto trágico (predeterminado), aunque de ningún modo incompatible con el valor artístico que la fábula trágica pueda alcanzar (como el mismo Aristóteles señala en 9, 51a-34-51b11, al referirse a la tarea del poeta como imitador de lo que podría ser) ${ }^{4}$. Más adelante, examinaré el papel que la compasión y el temor desempeñan en la composición de la fábula y la vinculación que Aristóteles establece entre el efecto trágico y el ethos que conviene a este tipo de mociones anímicas, pero quiero señalar desde ahora que la compasión al inocente y el temor por el semejante, modelo que halla su expresión más perfecta en el Edipo sofocleo ${ }^{5}$, no excluye otros modos de producir tales afecciones, según se desprende de Retórica (II, 1382a20-1383a10; 1385b10-1386b5) y del examen de las tragedias griegas conservadas ${ }^{6}$.

\footnotetext{
${ }^{3}$ En Bobes, C. (1995: 127-40). En realidad, las interpretaciones pueden integrarse en cuatro apartados: médicas, morales, estructurales y cognitivas. Las morales no difieren sustancialmente de las homeopáticas: como los malos humores, o los que son nocivos por exceso o defecto, también las pasiones se consideran patológicas, ya sea en sí mismas, ya sea en determinado grado. Las estructurales, por ejemplo, la que propone Gerard F. Else, para quien lo miarón, removido en el seno de la tragedia, produce el sufrimiento del héroe (como sucede en Edipo, pero no de forma tan clara en otras tragedias), y por lo tanto su purificación, ignoran al receptor (hacia el que Aristóteles orienta sin lugar a dudas el efecto trágico); también Ingemar Düring cree que la catarsis se refiere a la propia tragedia, no al efecto sobre los espectadores (Düring, 1987: 276). Las cognitivas, que interpretan la catarsis como clarificación (intelectual, o intelectual y emocional), hallan su fundamento en textos platónicos, de Epicuro y de Filodemo (cfr., por ejemplo, Golden, 1976: 437-452, y Domini, 1999: 26-41), y buscan acomodo en la consideración aristotélica de la poesía como forma de conocimiento. Aún podríamos añadir la teoría freudiana de la creación artística como descarga emocional de las pulsiones inconscientes del autor. En realidad, no andaba Brecht tan descaminado como parece al hablar del «lavado placentero», porque la insistencia en la máthesis trágica, como una especie de aprendizaje a través del sufrimiento, deja en penumbra el placer inherente a la recepción de la tragedia, placer que para Aristóteles, a diferencia de lo que sostenía Platón, era inofensivo y aun deseable para el buen orden de la ciudadanía, como se desprende de Política y como observa en la Ética a Nicómaco (1175b13-14), donde alude al placer específico de la tragedia y advierte de los riesgos que puede comportar una mala interpretación de los actores (concretamente, dice que el hecho de que los espectadores coman golosinas cuando asisten a una representación teatral, muestra que los actores son malos, pues no consiguen atrapar al público en la ilusión del espectáculo).

${ }^{4}$ Cfr. Collingwood (1938) y Kommerell (1984: 81-134).

${ }^{5} \mathrm{El}$ modelo de estructura ideal propuesto por Aristóteles, que responde inequívocamente al Edipo, no resulta satisfactorio para la mayor parte de las tragedias conservadas, como él mismo sugiere al hacer explícitas sus preferencias; la mejor composición de los hechos es aquella en la que la desdicha humana resulta de las propias decisiones (proairesis) y acciones del personaje, no por maldad, sino por hamartía, como veremos; pero esto no significa que excluya otras formas posibles de componer la fábula, en las que incluso tiene cabida lo miaron, lo moralmente repulsivo, como señala a propósito de Hemón en la Antígona (14, 1454a), o de Medea, que, como tantas otras heroínas de la tragedia, perpetra su terrible crimen con pleno conocimiento del vínculo que la une a sus hijos $(14,1453 \mathrm{~b} 27-30)$. No se puede sostener, en consecuencia, que Aristóteles subordine la poesía a la ética o que establezca pautas morales para la composición trágica: no es lo mismo, como él mismo afirma, la corrección de la política que la de la poética $(25,1460$ b13-15).

${ }^{6}$ En Retórica, enumera hasta once situaciones que pueden suscitar la compasión: entre los males dolorosos y destructivos, las muertes, la violencia física, los malos tratos, la vejez, las enfermedades y la falta de alimento; entre los grandes males originados por la fortuna, menciona la escasez o ausencia de amigos, la fealdad, la debilidad física, la invalidez y el que resulte un mal de aquello que era justo que resultase un bien, es decir, lo que en su análisis de la tragedia podría equipararse a la peripecia. Y aun añade que es especialmente digno de compasión que esto suceda muchas veces, así como el que venga a producirse algo bueno después de haber sucedido un mal terrible, o que la buena fortuna sobrevenga a alguien cuando ya no está en disposición de disfrutarla. De
} 
Una vez definida la tragedia, Aristóteles pasa a considerar sus partes cualitativas, que no enumera siempre en el mismo orden. Primero se refiere a la opsis, en correspondencia con el modo dramático, luego a la melopeia y la elocución (lexis) como medios de imitación (6, 49b32-50a5) y, finalmente, integra caracteres (ethos) y pensamientos (dianoia) en la acción imitada, es decir, en la fábula (6, 49b31 50a8-14). El actuando propio de la imitación dramática exige el espacio visible en el que se muestran los actores, de manera que opsis, todo lo que entra por los ojos, hace referencia al espacio escenográfico (independientemente de que se limite a la escena sin decoración añadida alguna, como el mismo Aristóteles cree que sucedía antes de que Sófocles introdujese la escenografía), al vestuario, máscaras, etc., y, por supuesto, a los espacios lúdicos creados por los gestos y movimientos de los actores en escena. La traducción del término opsis (visión, apariencia) ha sido muy discutida, pero es indudable que no puede referirse únicamente, como por ejemplo en Else, al aspecto visible de los actores (con su indumentaria). Por otro lado, al presentar la música y la elocución como partes independientes de la opsis, tampoco parece exacto identificarla con la noción de espectáculo, pero en todo caso está claro que Aristóteles hace referencia aquí a la presencia escénica de los actores, de manera que al modo dramático propio de la tragedia y la comedia (3, 48a20-48b) corresponde la mostracion ante los ojos (opsis).

A continuación define brevemente la elocución ${ }^{7}$, composición en verso, como

manera explícita, subraya la necesidad de que las personas que sufren estos males sean virtuosas y semejantes a nosotros (aspectos pertinentes para su valoración del ethos que conviene a los protagonistas de la tragedia). En lo que se refiere al temor, menciona los males destructores y dolorosos que pueden proceder de la enemistad, la ira, la injusticia, la virtud ultrajada, el estar a merced de otro, a manera de los cómplices en las malas acciones, la rivalidad, la fuerza física y también los que temen a los que son más fuertes que ellos; dicho de forma simple, todas las cosas que cuando les suceden, o están a punto de sucederles a otros, inspiran compasión. También hace referencia aquí al talante propio del hombre que puede puede experimentar temor ycompadecerse de las desdichas ajenas: ni los soberbios, que creen que no puede ocurrirles ningún mal y se muestran despectivos ante el dolor ajeno, ni los que se sienten completamente perdidos y permanecen impasibles porque consideran haber sufrido ya toda clase de desgracias. En Poética, no hallamos indicaciones explícitas sobre el tipo de público capaz de experimentar una reacción emocional adecuada a los sufrimientos trágicos, pero de ahí no se desprende, como sostiene la interpretación estructuralista de la catarsis, que haga referencia a los propios personajes de la tragedia, en el sentido en el que Aristóteles se refiere a la purificación ritual de Orestes en Ifigenia entre los tauros (17, 1455b15). Entiendo, además, que la compasión por un inocente y el temor por un semejante (Poética 13, 1453a5) se refiere de manera implícita a los espectadores o lectores de la tragedia.

${ }^{7}$ Algunas de las cuestiones relativas a la elocución corresponden al arte del actor y del director, no al del poeta - «por ejemplo, qué es un mandato y qué una súplica, una narración, una amenaza, una pregunta, una respuesta y demás modos semejantes» (19, 1456b10-15), de manera que a ellos ha de confiarse la adecuada ejecución quinésica y paralingüítica de la palabra. No resta importancia al juego interpretativo, del que puede depender el sentido mismo, pero deja a un lado cualquier consideración sobre un arte ajeno a la poesía. En este sentido, es suficientemente explícita la referencia a la censura que Protágoras hace del famoso Canta, ob diosa, la cólera... de Homero (19, 1456B15).

Otras, en cambio, corresponden al arte del poeta y merecen la especial atención del Estagirita, tanto en Poética como en Retórica. Es especialmente interesante, por sus implicaciones espectaculares, la metáfora dramática, que 
corresponde a la tragedia, y da por supuesto el sentido de melopeia, que estima el más importante de los «aderezos» o partes espectaculares de la tragedia ${ }^{8}$. Por último, considera el carácter y el pensamiento (cuyo análisis remite a Retórica) como causas de las acciones y, en consecuencia, los subordina a la fábula, la parte más importante de la tragedia $(6,50 \mathrm{a} 15$, 50a22-23, 50a29-32, 50a38-39; 7, 50b24), definida como imitación de una acción (6, 50a4), es decir, como composición de los hechos (6, 50a5, 50a15-16) $)^{9}$.

En la recapitulación que sigue, Aristóteles enumera caóticamente y por dos veces las partes de la tragedia, como corresponde al carácter acroamático del texto, pero queda claro que fábula, carácter y pensamiento constituyen el objeto imitado; elocución y canto los medios de imitación, y opsis el modo de imitar. De manera que la elocución constituye el soporte verbal de la fábula y el único medio del que dispone la mimesis trágica no representada ${ }^{10}$, mientras que la música y los aderezos visuales propios del montaje escénico, especialmente estos últimos, son ajenos al arte de la poesía (50b15-20). La fábula, en efecto, debe estar constituida de tal modo que, aun sin verlos, el que oiga el desarrollo de los hechos se atemorice y se compadezca por lo que acontece, en cambio, «producir esto mediante el espectáculo es menos artístico y exige gastos» (14, 53b3-8). Conviene, en cambio, que la

no solo pone algo ante los ojos (hipotiposis), sino que es capaz de «representarlo en acción», en curso, en movimiento. Cfr. Martínez (1983: 328-329).

${ }^{8}$ Aunque advierte que la melopeia es el más importante de los aderezos (6,1450b16-17), resulta sorprendente que Aristóteles menosprecie aquí las posibilidades catárticas de la música, especialmente de la música frigia, a la que tan alto valor concede en Política (VIII, 7, 1342a), potencialidades catárticas que, por lo demás, habían sido destacadas por la paideia griega y, en particular, por la tradición órfico-pitagórica, que consagra Platón, en relación con la psicogagía (guía del ethos) y con la catarsis. En cuanto al segundo de los aderezos, queda claro que hace referencia a los aspectos visuales del espectáculo teatral y a la interpretación verbal de los actores, innecesarios, como se ha dicho, para que se produzca la conmoción trágica. Sobre la valoración de la música en la tragedia, puede verse Nietzsche (1871: 80-87), quien, arrastrado sin duda por su entusiasmo wagneriano, ve en los cantos corales la esencia misma de la tragedia.

${ }_{9}^{9}$ La mimesis, en cuanto composición de los hechos (míticos, reales o inventados por el poeta), otorga a la tragedia el estatuto de ficción imprescindible para que pueda producirse el efecto catártico: frente al horror o estupor que producen los sucesos trágicos en la vida real, la tragedia muestra el sufrimiento humano trasmutado por la elaboración del poeta, de una forma bella e inteligible: huiríamos espantados ante la visión de una mujer capaz de asesinar a unos niños, pero recorremos un buen trecho para ver una buena representación de Medea o de Hécuba. Cfr. Janko (1992: 342). Curiosamente, la argucia de remitir al sueño del protagonista los acontecimientos trágicos narrados en La mujer del cuadro, uno de los ejemplos más elocuentes de la rentabilidad de la Poética para el análisis del cine clásico, pone de manifiesto esa faceta imaginaria -ficcional- indispensable para la catarsis, efecto que en la película se asocia al alivio placentero, puesto que nada ha sucedido si no en sueños, y al conocimiento, puesto que el personaje sale mejor preparado para afrontar en la vida real situaciones semejantes (de ahí, que rechace inmediatamente el acercamiento de la mujer que acude a él para pedirle fuego).

${ }^{10}$ No comparto la idea de que la lectura, como sostiene Elsen (1957: 137; 160-161), anule necesariamente la riqueza de matices de la lexis que la dicción del actor incorpora a la representación teatral. Sin entrar aquí a discutir el problema, y prescindiendo de que la lectura en voz alta era una práctica habitual en el mundo griego, sí quiero anotar que, en la medida en que un texto dramático sea leído como tal, requiere que el receptor visualice y «auricularice», si se me permite el término, una puesta en escena imaginaria, operación que exige cierta «competencia teatral», en efecto, pero que el propio texto propicia (sin necesidad de acotaciones exentas). 
composición de la fábula se perfeccione con la elocución, poniendo las situaciones «ante los propios ojos lo más vivamente posible», como si los hechos se presenciaran directamente (17, 55a22-25), es decir, mostrándolos a través del lenguaje más adecuado para que sea posible visualizar imaginariamente una puesta en escena de los conflictos y antagonismos que encadenan el proceso argumental. ${ }^{11}$

El interés de Aristóteles se centra en los aspectos literarios del teatro, los que constituyen el objeto de una poética - «para el montaje de los espectáculos es más valioso el arte del que fabrica los trastos que el de los poetas» (6, 50b20-21)- , pero no ignora que la dimensión espectacular de la tragedia se proyecta sobre la composición de la fábula, como se desprende de las observaciones relativas al cronotopo dramático, más intenso que extenso (5; 24; 26), o al tratamiento de lo maravilloso y lo irracional, más apropiado para la epopeya, «porque no se ve al que actúa» $(24,60 \mathrm{a} 14)$, que para la tragedia, en la que podría resultar inverosímil, al presentarse en escena, lo que «en la epopeya no se nota» (24,60a17). De ahí también la conveniencia de confiar el desenlace trágico a la composición de la fábula, reservando el deus ex machina «para lo que sucede fuera del drama, o para lo que sucedió antes de él sin que un hombre pueda saberlo, o para lo que sucederá después, que requiere predicción o anuncio; pues atribuimos a los dioses el verlo todo» (15, 54b2-5). Es preferible, en suma, que la fábula trágica evite los sucesos irracionales o los deje fuera del tiempo y del espacio representado, como sucede en el Edipo de Sófocles $(24,54 \mathrm{~b} 7) .{ }^{12}$

Por otra parte, Aristóteles reconoce la virtualidad escénica de la fábula trágica en sus repetidas alusiones al papel desempeñado por los mensajeros, o personajes que asuman momentáneamente esta función, porque a través de su relato, fidedigno a menos que medie información en sentido contrario, se proporcionan al lector o espectador noticias de lo que ocurre fuera del espacio visible de la escena (o del tiempo representado); y, en concreto, apunta la conveniencia de que los lances de carácter sangriento con los que suele culminar el pathos trágico se produzcan fuera del espacio visible de la escena, como era habitual por lo demás en la tragedia ática, que solía confiar a la palabra de los mensajeros-testigos el relato de tales sucesos: así, en Edipo rey, el mensajero que informa al Coro, y de paso al espectador, del suicidio de Yocasta en el interior de palacio (vv. 1223-1240), y más adelante del cruento

\footnotetext{
11 Sobre la hipotiposis y la presencia audiovisual en la escritura literaria, puede verse Villanueva (2008).

12 Efectivamente, la tragedia de Sófocles se inicia muchos años después de la muerte de Layo, de manera que la ignorancia de Edipo resulta así más creíble para el lector o espectador, que difícilmente admitiría tal desconocimiento si el crimen se perpetrase a la vista del espectador (o lector) y en la secuencia espacio-temporal de la tragedia.
} 
castigo que se inflige Edipo. También las referencias a sucesos acontecidos fuera del espacio o del tiempo representado se introducen a través del relato de mensajeros, como el ya mencionado del Sirviente que informa de la muerte del rey Pólibo y, para disuadir a Edipo del temor al incesto con Mérope, de sus verdaderos orígenes.

Parece evidente que la figura del Mensajero, o sus equivalentes funcionales, se vincula al teatro desde sus orígenes, precisamente por la necesidad de resolver los problemas espaciales y temporales que suscita la propia economía de la representación dramática. La anticipación visionaria de una acción futura solía insertarse en los estásimos cantados por el Coro, que también narraba y comentaba, o incluso vivía visionariamente, los enfrentamientos cruentos que tenían lugar fuera de la escena ${ }^{13}$; y tanto la resis como las partes dialógicas podían dar noticia de los sucesos del pasado pertinentes para la comprensión de la acción (así el Prólogo de este tipo), o de los acaecidos durante su transcurso en lugares no visibles para el espectador. De ahí que la Poética aristotélica preste especial atención al principio constructivo específico del modo dramático -la oposición dentro/fuera, presencia/ausencia-, pues la composición de la fábula trágica ha de prever que no todo el mundo ficcional va a ser mostrado directamente al lector o espectador en el espacio escénico.

Desde Esquilo, observamos en algunas tragedias griegas la coalescencia entre la visión de una imagen ofrecida a través del punto de vista de un mensajero, o equivalente funcional, y su presentación escénica a la vista del espectador (como tantas veces sucede en los dramas de Shakespeare). Así, en el Prólogo de Euménides, la Pitia sale horrorizada del templo e inicia su relato de la espantosa visión que ha contemplado en el interior de la gruta: Algo terrible de contar, algo horrible de ver con los propios ojos me ha echado fuera del templo de Loxias, hasta el punto de que me faltan las fuerzas y no puedo mantenerme en pie, sino que corro ayudándome con las manos, no con la ligereza de mis piernas, pues una anciana asustada no tiene valor para nada, es como una niña (vv. 34-40). El relato se transforma inmediatamente en una descripción minuciosa y detallada de su visión, una hipotiposis, que la Pitia ofrece a modo de acotación escénica: sobre la piedra que en el templo de Apolo simbolizaba el centro de la tierra, un hombre (Orestes), está sentado como suplicante. Gotean sangre sus manos. Lleva una espada recién sacada de la herida y levanta un ramo de olivo [...]. Delante de este hombre, duerme un extraño grupo de mujeres [...], son de color negro y en todo reugnantes: roncan con resoplidos repelentes y de sus ojos segregan humores odiosos [...] (vv. 40-55). E inmediatamente, Orestes y las Erinias aparecen ante el espectador, como

${ }^{13}$ Cfr. Rodríguez Adrados (1983: 121-124). 
se desprende de las palabras de Apolo dirigidas al matricida: Ahora mismo, atrapadas, estás viendo a estas furias rendidas por el sueño, las despreciables vírgenes, etc. (vv. 66-70). La espantosa imagen de las furias dormidas será corroborada por la sombra de Clitemnestra, que les reprocha la despreocupación por su dolor y las insta a la venganza, mientras ellas gruñen somnolientas (vv. 94-140). La presencia escénica de las Erinias en la última pieza de la trilogía, y la insistencia del texto en poner de manifiesto esa presencia desde el punto de vista de diferentes personajes, responde a la necesidad de otorgar plena existencia ficcional a las rencorosas vengadoras que en Coéforas solo existen en la mente perturbada por la culpa de Orestes: Vosotras [las mujeres del coro] no las veis, pero yo estoy viéndolas (vv. 1062-1064). Se inaugura en esta trilogía de Esquilo el procedimiento de autentificación/desautentificación de los mundos dramáticos canónico en la tradición dramática occidental (el mismo que, por ejemplo, confiere al espectro del rey Hamlet plena existencia en sus primeras apariciones, pero hace más que dudosa su presencia en el gabinete de la reina Gertrudis).

Aristóteles es plenamente consciente de que la palabra puede, por sí misma, otorgar plena existencia al mundo ficcional de la tragedia, del que también forman parte todos los signos verbales que en la representación se actualizan, o pueden actualizarse, por otros medios, de manera que la tragedia puede existir sin representación y sin actores, es decir, como texto dramático, y su efecto específico, añade, ha de proceder de la composición de la fábula, sin necesidad de los ornamentos propios del espectáculo teatral ¿Quiere esto decir que Aristóteles otorgue prioridad al texto dramático en detrimento de la puesta en escena teatral? No lo creo. Él mismo es el autor de las Didascalias, texto esencial para la historia de la escena, y sabe que el éxito o fracaso de las obras, independientemente de los valores literarios del texto, depende de la maestría de los que la ejecutan en escena, aspecto que por sí mismo explica el papel decisivo que atribuye a la opsis. Se trata más bien de una decisión acerca de su objeto de conocimiento: no ignora que la tragedia, y en general los géneros dramáticos, forman parte de la institución teatral, a la que él mismo se refiere en repetidas ocasiones, pero su Poética se interesa por «el arte que imita solo con el lenguaje, en prosa o en verso» (I, 47b), del que dice que «carece de nombre hasta ahora» (I, 47b10), es decir, se interesa por la tragedia como asunto literario. Otra cosa es que en la tradición logocéntrica occidental el peso de Aristóteles haya influido en la consideración jerárquica de las artes y, en particular, en el desprecio hacia la opsis, que ya se puede rastrear en la iconofobia platónica. No está de más advertir de pasada que el escenocentrismo de algunos estudios actuales ha dejado en penumbra la dimensión literaria de los estudios dramáticos y ha llevado a 
consideraciones que, desde mi punto de vista, no son admisibles. Por ejemplo, la equiparación de la literatura dramática con el guion cinematográfico, que parece ignorar la existencia misma de la institución literaria (otra cosa muy distinta es que la Poética sea un espléndido manual para la escritura del guion). Es cierto que la teoría del teatro no ha sido totalmente ajena a la convención mimética, de enorme utilidad para trazar los límites del teatro con artes escénicas fronterizas, pero la necesidad de deslindar el teatro de la literatura dramática acaparó la atención de gran parte de las investigaciones desarrolladas en Europa en las últimas décadas del siglo pasado en detrimento de los problemas relativos a la producción de ficción. Y buena prueba de ello es el escaso interés que ha suscitado la autentificación de los mundos ficcionales dramáticos, a la que he dedicado atención en otro $\operatorname{lugar}^{14}$. El interés por la ficción teatral se suscita, significativamente, una vez zanjada la disputa en torno a la condición esencialmente espectacular del arte dramático y a la virtualidad escénica de los textos que componen la literatura dramática, virtualidad que, como hemos dicho, no es ajena a la teoría aristotélica de la tragedia.

Por otra parte, la Poética de Aristóteles está repleta de referencias literarias. Es una poética universalista, y como tal se desentiende de la interpretación de las obras concretas, pero es también una poética ejemplificatoria y valorativa ${ }^{15}$, es decir, no se limita a hacer afirmaciones descriptivas, sino que formula una y otra vez juicios críticos sobre tragedias (y epopeyas) en función de su mayor o menor adecuación al modelo elaborado. Es una «teoría de la estructura ideal» basada en el conocimiento de las tragedias existentes y construida a partir de un corpus axiológicamente seleccionado; se trata de una axiología estética intuitiva (racionalmente intuitiva), no explícita (aunque queda bien reflejada en la selección de sus ejemplos), a la que se subordina la construcción de un modelo cuyas normas estructurales y funcionales constituyen el criterio valorativo. Está claro, como ya hemos dicho, que un modelo de este tipo no puede explicar satisfactoriamente la gran variedad que ofrecen las tragedias conservadas; solo un porcentaje mínimo, según Else, se adaptaría a la estructura ideal propuesta por Aristóteles, que se refiere a unas sesenta obras trágicas, gran parte de ellas desconocidas para nosotros, y mira directamente hacia el Edipo sofocleo, como comprobaremos enseguida. Su teoría se ofrece, fundamentalmente, en torno a las obras de Sófocles, con el que la tragedia, asegura, ha alcanzado su plenitud, Euripides, del que afirma, refiriéndose al desenlace catastrófico de algunas de sus fábulas, que «es el más trágico de los

${ }^{14}$ Cueto (2012: 629-645).

15 Doležel (1990). 
poetas» $(13,1453 \mathrm{a} 30)^{16}$, y sus epígonos, muchos de ellos desconocidos para nosotros. Las alusiones a Esquilo son de menor calado, excepto que en el capítulo cuatro le atribuye la introducción de un segundo actor (hecho que por sí mismo le otorga un lugar de privilegio en la tragedia griega y en la historia del teatro) y la disminución de las intervenciones corales, concediendo mayor importancia al diálogo (4, 49a16-18); más adelante, encontramos una referencia a la anagnórisis que procede de un silogismo de Coéforos (16, 1455a5), y en el capítulo 18 (1456a15-20), condena a los que dramatizaron entera la historia de la destrucción de Troya, y no por partes como Eurípides, «o la historia de Niobe, y no como Esquilo». También elogia la lexis de Eurípides al componer el mismo verso yámbico de Filoctetes sustituyendo el vulgar come de Esquilo -una úlcera que come las carnes de mi pie- por el más apropiado devora (22, 58b20-25).

No es, pues, una teoría abstracta y desvinculada del arte trágico: conoce muy bien la tragedia como literatura y como institución teatral y la valora, atribuyéndole un papel importantísimo en los pasajes de Política dedicados la educación de los jóvenes ciudadanos, en clara oposición a las ideas sostenidas por su maestro. Está claro, en definitiva, que la elección de los aspectos literarios del drama, dejando de lado los relativos a la puesta en escena, responde a una deliberada decisión sobre su objeto de estudio, en congruencia con el asunto del que se ocupa su Poética.

\section{SOBRE LA ACCIÓN. MITO Y FÁBULA.}

El término mythos se utiliza en la Poética tanto para designar lo que aquí hemos traducido por fábula (la composición de los hechos tal como se ofrecen, por ejemplo, en Edipo rey) como para designar el material mítico (por ejemplo, la historia de Edipo previa a

\footnotetext{
${ }^{16}$ Son muchas las tragedias de Eurípides que se apartan del modelo aristotélico, tanto por sus frecuentes innovaciones en el tratamiento del mito como por el papel que concede al azar en la composición de sus tramas, especialmente en las tragedias novelescas, de intriga complicada y carácter tragicómico,como Helena, Ion, o Ififenia entre los tauros, cuyos precedentes ya están en el Alcestis, la última pieza de una tetralogía perdida representada en el año 438 (compuesta por Las cretenses, Alcmeón en Psofis, Télefo y el drama satírico Alcestis, que se ha conservado intacto y ofrece ya muchos rasgos característicos de la tragedia de Eurípides). La Ifigenia entre los tauros, como veremos, se valora en la Poética por su potencialidad catártica, que no implica necesariamente una valoración estética. En cuanto a su consideración de Eurípides como el más trágico de los poetas, ha de tenerse en cuenta que Aristóteles se refiere únicamente a los desenlaces catastróficos de algunas de sus tragedias, pues esto, según hemos dicho, es correcto. Y lo prueba insuperablemente el hecho de que, en la escena y en los concursos, tales obras son consideradas como las más trágicas, si se representan debidamente, y Eurípides, aunque no administra bien los demás recursos, se muestra, no obstante, el más trágico de los poetas (Poética, 13, 1453a25-30).
} 
la tragedia de Sófocles) y, en general, los hechos acreditados por la tradición. Acreditados por la tradición no significa en absoluto que tales hechos hayan acaecido en efecto, ni que el receptor crea en su facticidad, sino que se han incorporado a la conciencia colectiva con la autoridad de lo relatado a menudo. Esa autoridad del mito es importantísima en la teoría aristotélica, puesto que permite conciliar dos exigencias opuestas: lo verosímil (creíble) y lo extraordinario (acreditado por el mito y, en consecuencia, apriorizado como verosímil). Por otra parte, no cabe duda de que el mito es fuente de materiales especialmente aptos para la tragedia, ya que contiene en si mismo casos extremos, inesperados y profundamente conmovedores, repletos de pathos humano, de peripecias y anagnórisis particularmente adecuadas para la composición de la fábula. Esto ha hecho pensar a algunos comentaristas que el factor mítico es esencial y necesariamente constitutivo de la tragedia ática (García Yebra, 1974: 276, nota 151); sin embargo, Aristóteles admite la posibilidad de que la fábula verse sobre acontecimientos reales o inventados por el poeta $(9,51 \mathrm{~b} 19-24 ; 14,53 \mathrm{~b} 25-26)$, es decir, acontecimientos que no pertenezcan al acervo tradicional, a condición de que satisfagan las exigencias de la fabula trágica (que se integren en unidad y resulten verosímiles, que presenten situaciones de intenso sufrimiento, que los caracteres reúnan los requisitos propios de la tragedia, etc.). Si en el primer caso, la verosimilitud era inherente al mito, fuertemente asentado en la creencia general, en el caso de los sucesos aportados por el poeta la credibilidad depende tanto de la composición de la fábula como de la adecuación a la doxa (saber común); de manera que Aristóteles recomienda fidelidad a los tipos consagrados por la tradición, si el poeta fabula sobre un tema mítico preexistente $(14,53 b-23-25)$ y adecuación a las expectativas doxáticas, si fabula sobre un tema de su invención (en este sentido ha de entenderse su oscura y chocante observación sobre los caracteres femeninos de la tragedia -no es apropiado a una mujer ser varonil o temible $(15,54 \mathrm{a} 23-25)$ — sobre la que volveremos más adelante).

Más atento a la composición de la fábula que a la presencia en ella de un pasado legendario todavía vivo en el horizonte de producción (y recepción inmediata) de la tragedia, Aristóteles da cabida en ella a nuevas formas dramáticas que, en rigor, ya no corresponden al momento trágico. El momento de la tragedia, que surge, se perfecciona y desaparece en el curso de un siglo, es aquel en el que se abre en el seno de la comunidad una brecha «lo bastante grande para que entre el pensamiento jurídico y político, por un lado, y las tradiciones míticas y heroicas, por el otro, se esbocen claramente las oposiciones; pero lo bastante leve a la vez para que los conflictos de valor se sientan todavía dolorosamente y la 
confrontación no deje de llevarse a cabo» (Vernant y Vidal Naquet, 1972: 18) ${ }^{17}$. O, como observa atinadamente Walter Nestle, en la tragedia el mito se contempla con ojos de ciudadano, se cuestiona, y a través de él, es la propia ciudad la que se cuestiona a sí misma. Este aspecto es especialmente relevante en el terreno jurídico, en un momento en el que el derecho está en pleno proceso de constitución y las antiguas leyes conviven con las del nuevo orden democrático de la polis anteniense. El ejemplo paradigmático está en la Antígona de Sófocles: ni Antígona ni Creonte son epieikeis ${ }^{18}$, excelentes, porque ninguno de ellos alcanza a cuestionarse la ley que se obstina en defender a cualquier precio, de ahí la simplificación de valores que convierte el diálogo trágico en un diálogo de sordos; ambas leyes, la vieja y la nueva, coexisten en el seno de la polis y no pueden suplantarse, ni por imposición, como pretende el tirano, ni por desobediencia, como quiere Antígona. Y ambos habrán de reconocer las limitaciones de su planteamiento: Antígona porque ha identificado la piedad, la justicia y la religión con los deberes hacia los muertos, renunciando al amor, a la continuidad de su linaje y a la propia vida; Creonte porque ha de experimentar amargamente el valor verdadero de los lazos familiares que ha supeditado a su idea del bien civil ${ }^{19}$.

El desdoblamiento entre el personaje trágico y el coro responde también a esta tensión inherente a la acción trágica: de un lado, el héroe legendario, siempre representado por un actor profesional e individualizado por la máscara, no en un sentido psicológico, sino precisamente como encarnación de ese pasado heroico; de otro lado el coro, al parecer no enmascarado sino únicamente disfrazado, que representa a un grupo de ciudadanos y expresa a los espectadores que componen la comunidad cívica sus temores y esperanzas, sus juicios y sentimientos ante lo que sucede en escena, ante la acción protagonizada por esos héroes de un pasado más o menos ajeno a la condición ordinaria de los ciudadanos. A este desdoblamiento corresponde, como es sabido, un espacio diferenciado en la representación teatral: el coro ocupa el lugar de la orquestra, entre los espectadores y los actores, cuya acción se desarrolla en el proscenio, ante la skéne; los límites entre ambos espacios pueden ser vulnerados (y lo son con relativa frecuencia, sobre todo en Eurípides), pero su separación es

\footnotetext{
${ }^{17}$ En cierto sentido, se podría asimilar el universo mítico de la tragedia a lo que Murray, refiriéndose a la esfera del pensamiento religioso, llama con acierto Conglomerado Heredado, es decir, al esquema de creencias del pasado que convive con los nuevos modelos, a veces de forma inconsciente, incluso en un mismo individuo. Para estas cuestiones, puede verse «Racionalismo y reacción en la época clásica», en Dodds (1951: 171-194); no cabe duda de que Eurípides, con el que la tragedia ática se desliza hacia un plano humano, debió de escandalizar a los sectores más conservadores del auditorio griego de su época, acostumbrado a los moldes heroicos del teatro de sus predecesores.

${ }^{18}$ Cfr. Ética a Nicomaco V, 10, 1137b99.

${ }^{19}$ Hegel (1835: 510-554). Cfr. los comentarios al respecto de Steiner (1984: 15-42).
} 
la condición misma de la transgresión, percibida como tal por los espectadores ${ }^{20}$. Por otra parte, el desdoblamiento entre el héroe mítico y el coro se manifiesta en la propia lengua de la tragedia: la lírica coral, en las partes cantadas, frente al diálogo, cuya métrica se halla cerca de la prosa, en las partes recitadas por los actores; paradójicamente, los personajes heroicos, representantes del pasado mítico, se expresan en un lenguaje más cernano al de los hombres corrientes que el coro, cuyo lenguaje prolonga la tradición lírica, pero a diferencia de Simónides o de Píndaro, estas partes cantadas ya no son una exaltación de las virtudes ejemplares del héroe: expresan más bien inquietud, se preguntan sobre él, comentan sus acciones. Es una prueba más de la ambigüedad que caracteriza a la tragedia: los personajes heroicos, alejados en el tiempo de la ciudad, se hacen presentes en escena ante los espectadores y se aproximan a ellos a través de un diálogo prosaico (así el sjedon, tan sorprendente en Sófocles), por medio del que se enfrentan entre sí y se enfrentan a su vez a los coristas, es decir, se convierten en objeto de discusión, de debate: el héroe ha dejado de ser un modelo, se ha convertido, para él, para el coro, para los espectadores, en un problema. Significativamente, mientras la máscara le confiere en la representación esa dimensión heroica y esa grandeza propia de los seres excepcionales del pasado, su lenguaje lo aproxima a la conversación ordinaria del hombre común ${ }^{21}$.

Se entiende ahora que el momento trágico coincida con ese apretado marco temporal en el que, en el espacio de un siglo, vemos surgir, florecer y desaparecer la tragedia ática: se podría decir que ese momento se sitúa entre dos fechas que señalan dos actitudes opuestas ante el espectáculo trágico: la cólera de Solón cuando abandona una de las primeras representaciones, antes de la institución como tal de los concursos trágicos, de la que nos da noticia Plutarco, y la referencia de Aristóteles a Agatón, contemporáneo de Eurípides, que escribía tragedias sobre asuntos de su propia invención. Para el viejo legislador, que hubo de doblegar el orgullo de los nobles para fundar el orden de la ciudad, el pasado «heroico» se hallaba todavía demasiado cercano como para ser llevado a la escena sin hacer peligrar, o sin

\footnotetext{
${ }^{20}$ Cfr., Benedetto y Medda (1997), Bobes (2001) y Cueto (2007: 4-10).

${ }^{21}$ Los personajes del Coro, representación colectiva del pueblo, no llevaban máscara, mientras que los actores (profesionales) que encarnaban a los héroes trágicos se individualizaban y engrandecían con ella: «Sobre la escena, los actores imitan a los héroes porque, en los antiguos, solo los héroes eran jefes y reyes: el pueblo era el común de los hombres, que componen el coro» (Aristóteles, Problemata 19, 48)., Sin embargo, las partes cantadas del coro son las que prolongan la tradición lirica de los himnos en honor de los dioses y de las alabanzas a las virtudes ejemplares de los héroes antiguos, mientras que los diálogos entre los protagonistas se aproximan más a la prosa: «De todos los metros, el trímetro yámbico es el más apropiado para el tono de la conversación: indicio de ello es que en el diálogo hacemos un gran número de trímetros yámbicos, raramente hexámetros, y esto solamente cuando nos apartamos del tono de la conversación» (Aristóteles, Poetica, 49a24-28).
} 
que él crea que puedan peligrar, las relaciones entre los ciudadanos; en Agatón, el vínculo con el pasado legendario se ha roto, se ha distendido tanto que en ese momento ya no se percibía la necesidad de un debate con el mito: pueden escribirse piezas y pueden inventarse tramas según el modelo antiguo, pero la tragedia griega como tal ha sido liquidada (Vernant y Vidal Naquet, 1972: 19).

Es comprensible que, por la índole misma de la acción trágica, esa tensión inherente al mythos (en tanto mito y fábula) se manifieste también «los hombres que actúan», en los ethe de la tragedia (causa, dice Aristóteles, de las acciones): el mismo personaje aparece proyectado a un pasado lejano, investido de todos los atributos de los héroes legendarios, pero en un presente que lo aproxima, en el plano humano, a sus conciudadanos atenienses. Esta ambigüedad se revela sobre todo en el daimon, la intervención de un poder del más allá que supera al personaje y se adueña de su carácter: en Los siete contra Tebas, Eteocles representa el pensamiento y los valores de la polis hasta que se apodera de él la furia destructora de los labdácidas y se precipita hacia la catástrofe. El mismo personaje que se ha enfrentado a la antigua religiosidad emotiva de las mujeres tebanas y ha rechazado la impiedad guerrera de los hombres de Argos, el que encarnaba al frente de Tebas la moderación civica, escucha del mensajero el nombre de su hermano y es transportado al universo del mito, a la maldición fratricida proferida por Edipo contra sus hijos: ¡Oh locura venida de los dioses y odio poderoso de las deidades! ¡Ob raza de Edipo mía, totalmente digna de lágrimas! ¡Ay de mi, ahora llegan a su cumplimiento las maldiciones de nuestro padre! (653-656) 22 .

La causa de las acciones, el ethos, es inseparable en la tragedia griega del daimon y no es posible concebir el carácter al margen de esta dualidad (pasado legendario/nuevo orden cívico) que constituye su esencia, precisamente en el momento en el que la acción humana se convierte en objeto de reflexión, pero sin haber adquirido todavía pleno estatuto de autonomía, porque los actos humanos se articulan con las potencias divinas y se insertan en un orden que sobrepasa al hombre y se le escapa. La voluntad y la libertad, tal como nosotros las entendemos, no forman parten del horizonte de producción y recepción inmediata de la

\footnotetext{
${ }^{22}$ La maldición heredada, que ocupa un papel central en la tragedia griega hasta Eurípides, se inserta en la idea de una justicia cósmica que, más tarde o más temprano, exige el castigo de los crímenes de los antepasados. En la Grecia arcaica era una ley religiosa de aplicación cívica, a pesar de que comportaba el sufrimiento de inocentes; la importancia de la familia, que Grecia compartía con otras comunidades primitivas, propició su penetración en la moralidad social hasta la aparición de la democracia ateniense y el derecho profano, pero el fantasma de esa antigua Moira no dejó de atormentar a los espíritus religiosos de la nueva polis. Esquilo, como veremos, intenta mostrar que esa culpa familiar puede romperse ( $c f r$. «De una cultura de vergüenza a una cultura de culpabilidad», en Dodds (1951: 39-70); también Girard (1972). Las citas de Sófocles corresponden a la traducción de Assela Alamillo (1981).
} 
tragedia griega, aunque muchas de ellas, y de ahí su valor, sean capaces de revelar, mejor que cualquier tratado filosófico, la fragilidad de nuestra condición humana. Sobre ello volveremos más adelante, a propósito de los vínculos entre la peripecia y la hamartía, el yerro que echa a andar la maquinaria de la tragedia y pone de manifiesto el nexo estructural entre acción y carácter en las mejores composiciones.

De momento, importa que exploremos con detenimiento la definición de fábula y, en particular, el sentido que el concepto de eudaimonía tiene en este y en otros pasajes de Aristóteles (Nussbaum, 1986: 470, nota 2). Ya hemos dicho que la composisión de los hechos es para Aristóteles la parte esencial de la tragedia; sin fábula, señala repetidamente, no puede haber tragedia, porque la tragedia no es una representación de seres humanos, sino «de la acción y el curso de una vida [bios]. Y la eudaimonía y su contrario consisten en acción, y el fin es cierta clase de acción, no una característica [poiotés]. Según sus caracteres [ta éthe], los individuos son de tales y cuales características [poiotés], pero es según sus acciones como viven bien (son eudaimones) o lo contrario» (1450a15-20). No ha de entenderse, por tanto, en sentido pasivo, por ejemplo, como felicidad, sino en un sentido activo: es la vida buena, pero en curso, en su desarrollo, procesualmente, de manera que el argumento de Aristóteles es el siguiente: la fábula es lo más importante porque la tragedia es una representación de la acción y la vida, no de estados de carácter. Por su carácter los individuos son de tales o cuales características, pero es según sus acciones como viven bien (es decir, son eudaimones) o lo contrario. En sentido estricto no quiere decir que los caracteres se subordinen a la acción, por ejemplo, en importancia, o que prefiera las tragedias con mucha acción, sino que lo específico de la tragedia no está en el mero ser de cierta persona sino en cómo afronta la vida. La tragedia no puede limitarse a presentar caracteres, como otros géneros literarios que Aristóteles conoce (las alabanzas a los hombres buenos, que Platón elogiaba en su República o los Caracteres de su discípulo Teofrasto), sino que ha de presentarlos en acción. Ser bueno, o tener un carácter bueno, no garantiza la endaimonía: por eso Aristóteles otorga a la tragedia un papel capital en la educación.

La superioridad que Aristóteles concede a las acciones sobre los estados es un lugar común en su filosofía y no constituye, por lo tanto, nada novedoso ni digno de mayor comentario. Lo que le interesa subrayar aquí es que ningún estado de carácter -por ejemplo, el ser bueno- basta para la eudaimonía, para alcanzar la plenitud de una vida buena. Y no es cuestión de escaso calado, pues está tomando una postura novedosa en la filosofía de su tiempo: está suponiendo, como también hace en Magna moralia, en la Eudemia y en Etica a 
Nicómaco, que un hombre bueno puede verse privado de felicidad a causa de sucesos que no está en su mano controlar. Desde luego, está lejos de la identificación entre la eudaimonia y la invulnerabilidad que Platón atribuía a las actividades del alma racional: también las «gentes buenas y justas», cuya vida no precisa nada del exterior porque han alcanzado, según Platón, una especie de autosuficiencia racional, pueden ser gravemente afectadas por circunstancias adversas. Y, efectivamente, se podría decir que la tragedia griega está ahí para mostrar que nadie está a salvo de la adversidad, que ningún mortal-como sentencia el Corifeo al final de Edipo rey-puede considerar a nadie feliz, hasta que llegue al término de su vida sin haber sufrido nada doloroso (vv. 1529-1530).

Las relaciones entre el hombre y lo divino se plantean de forma distinta en la obra de los tres grandes trágicos, incluso el concepto mismo de divinidad difiere en ellos a medida que el racionalismo va impregnando la cultura griega: en Esquilo, el más optimista de los trágicos, el cosmos divino todavía no aparece plenamente disociado del ámbito humano; en Sófocles lo humano se deslinda de la esfera de los dioses y el destino se impone desde fuera, como algo ininteligible y doloroso pero necesario para que el hombre adquiera plena conciencia de sí mismo y de sus limitaciones; en Eurípides, el vínculo con la divinidad se ha roto y el hombre ha de salvaguardar su dignidad por sí mismo, en pugna con sus propias pasiones o sorteando las embestidas del azar. Pero en todos ellos se pone de manifiesto la vulnerabilidad humana, la fragilidad del bien ${ }^{23}$.

\section{SOBRE LA COMPOSICIÓN DE LA FÁBULA.}

En todo caso, Aristóteles insiste en que la fábula debe ser imitación de una sola acción, entera y completa, de cierta magnitud $(7,50 \mathrm{~b} 25)$, cuyas partes han de estar enlazadas entre sí no de manera fortuita, sino por necesidad, de modo que la supresión o alteración de una de ellas comporte una modificación del conjunto $(8,51 \mathrm{a} 30-37$; 9, 52a2; 9, 52a23; 59a1730). Una acción es completa (teleia) si es llevada a su término o fin, fin establecido por el propio poeta, que, de modo consecuente, desarrollará solo aquellos hechos que sean necesarios y verosímiles para alcanzar tal fin. La fábula es entera (bolos) cuando tiene

\footnotetext{
${ }^{23}$ Este es, precisamente, el acertado título del ensayo citado que Nussbaum dedica a las relaciones entre ética y tragedia; para el planteamiento de las tensiones entre el hombre y la divinidad en los tres grandes trágicos, puede verse, por ejemplo, la síntesis de Jaeger (1933: 223-262, 303-324).
} 
principio, medio y fin (7, 50b26-27) y, como hace notar Ricoeur (1983: 96) solo en función de la composición poética adquiere algo el valor de principio, medio o fin. Así, el propio Aristóteles señala que se considera principio lo que no sigue necesariamente a otra cosa ( 7 , 50b28-29); fin, lo que sigue a otra cosa por naturaleza o necesidad y no es seguido por nada más (7, 50b29-31), y medio, lo que sigue a algo y viene seguido por algo (7, 50b31-32). De manera que la disposición de la fábula no procede de una ordenación previa, sino que es fruto de la composición poética, del proceso de mimesis activa que otorga valor literario al hipotexto mítico, como se pone de manifiesto de modo paradigmático en Edipo rey, prototipo sofocleo del drama analítico.

El que la fábula deba imitar una sola acción (el acontecimiento mítico, por antonomasia), entera y completa, son tres requisitos ligados por una exigencia mutua, ya que la unidad supone la integración en uno de lo múltiple, y la totalidad (completa y entera) diferencia y establece la unidad. Estamos, pues, ante una concepción orgánica, unitaria y totalizadora de la obra poética, pero no ante una definición de la integridad de lo trágico de carácter meramente estructural, ya que la estructura, además de unidad y totalidad, debe poseer como atributo una cierta extensión (megethos): la extensión requerida para que, de forma necesaria y verosímil, se produzca el cambio de fortuna (metabolé) en el caso de las fábulas simples; en las fábulas complejas, la extensión requerida para que dé tiempo a establecer el nexo entre el error trágico y sus consecuencias (7, 51a10-15). Aunque la extensión es una exigencia interna de la propia fábula, implica indiscutiblemente una concepción pragmática: la fábula así construida será fácilmente retenida en la memoria, y, dada la concatenación causal que rige la sucesión de los hechos, racionalmente aprehendida por el público, factores ambos que propician el efecto trágico. Ese encauzamiento de la fábula hacia la catarsis, dejando fuera lo episódico e innecesario (9, 51b33-35), es también lo que determina la mayor unidad de acción y la menor extensión de la tragedia respecto de la epopeya, como pone de manifiesto Aristóteles al subrayar que no ha de confundirse la unidad de la fábula con la unidad del personaje, ya que a uno solo pueden acaecer muchas y muy diferentes acciones no necesariamente relacionadas entre sí (8, 51a15-20).

De la composición de la fábula, ya sea a partir de mitos preexistentes o de personajes y hechos ficticios, no solo depende la conmoción trágica, sino el valor que la tragedia pueda alcanzar como forma de conocimiento: la poesía es más filosófica que la historia porque dice más bien lo general, aunque ponga nombres a los personajes ( 9 , 51b5-10). Esa «universalidad» es el resultado que arroja la producción mimética, cuya tarea bascula siempre 
del lado de lo que podría ser, pero plasmado en personajes y vivencias concretas, de manera que la tragedia -la literatura, en general- constituye (o, más precisamente, puede constituir) una forma de conocimiento y de ahí la importancia que le otorga para la educación de los jóvenes. Los casos particulares que muestra una buena tragedia contienen más verdad sobre la vida humana que cualquier fórmula general que de ellos pudiera extraerse, porque, como dice Nussbaum (1986: 44), «descubrimos lo que pensamos sobre los acontecimientos que se nos muestran apercibiéndonos de lo que sentimos» ${ }^{24}$.

Las consideraciones de Aristóteles sobre la fábula, la parte de la tragedia esencial y a la que concede mayor atención, son el mejor ejemplo del modelo mereológico dominante, según Doležel (1990: 38-44), en la Poética: a la definición de la tragedia como parte de la poesía (según el medio, modo y objeto de imitación), sigue la consideración de sus partes y, en particular, la fábula, de cuyas partes pasa a ocuparse al establecer la diferencia entre fábulas simples y fábulas complejas (10, 52a12-15).

Son simples aquellas fábulas en las que el cambio de fortuna se produce sin peripecia ni anagnórisis; son complejas, y más perfectas (13: 52b32), aquellas en las que el cambio de fortuna va acompañado de anagnórisis, de peripecia o de ambas. No menciona aquí la tercera de las partes de la fábula, el pathos, indispensable para que la tragedia pueda producir su efecto específico y común, por lo tanto, a las fábulas simples y a las complejas.

\section{SOBRE LA PERIPECIA (PERIPETEIA)}

Aristóteles define la peripecia como el cambio de acción en sentido contrario (11, 52a22) $\mathrm{y}$, de acuerdo con las normas preferenciales de la estructura trágica, subraya que tal giro, o revés, ha de producirse de modo forzoso y verosímil. No se trata de un cambio de situación (metabolé) que pueda llevar al héroe de la dicha a la desdicha o viceversa, requisito de toda tragedia concebida como acontecimiento de desarrollo progresivo (y presente en las fábulas simples, es decir, sin peripecia ni anagnórisis), sino de un efecto paradójico de la decisión del agente (proairesis), es decir, de una acción que, emprendida en determinado sentido, alcanza, sin embargo, un resultado opuesto: «La peripecia se diferencia del simple cambio de situación

\footnotetext{
24 La autora argumenta, con buen criterio, sobre la imposibilidad de prescindir de la poesía en el contexto de una investigación ética y advierte sobre el papel crucial que las respuestas emotivas desempeñan en el proceso cognoscitivo de la concepción ética incorporada en el texto trágico. En la misma línea se examinan las relaciones entre ética y tragedia en Trueba Atienza (2002).
} 
por su referencia a la interpretación. La peripecia puede ser dos cosas: el acontecimiento toma un giro que es una inversión de lo esperado o algo emprendido termina de tal manera que se opone a la intención del que lo había emprendido» (Kommerell, 1984: 161). El ejemplo elegido por Aristóteles procede del Edipo: para librar al rey tebano del temor al incesto con Mérope, el mensajero de Corinto le revela sus orígenes; de lo que creía un bien, resulta un mal: esa es la peripecia. Como puede verse, en el ejemplo que Aristóteles ha elegido aquí el sujeto de la peripecia -y el que yerra en su intención- es el mensajero corintio, aunque la víctima sea sin duda Edipo: se puede admitir, por tanto, que la peripecia ocupe el lugar central de la acción trágica o que haga referencia a alguna acción secundaria. En realidad, Edipo es una cadena sucesiva de peripecias, pues cada una de las acciones emprendidas por el rey tebano - desde que envía a su cuñado Creonte a consultar el oráculo hasta que interroga al criado que lo ha salvado- produce un efecto contrario al esperado e implica un progresivo proceso de reconocimiento que culmina en el pathos final: todo se ha revelado contra la proairesis del protagonista, tanto los hechos que ha llevado a cabo en el pasado, parricidio e incesto, como su investigación en el presente de la tragedia: cada paso que da para hallar al culpable del antiguo crimen, la mancha que contamina a la ciudad, lo implica irremediablemente como asesino y como pharmakós. La investigación emprendida por Edipo, su deseo de saber a cualquier precio, es lo que convierte al rey tebano en sujeto de la peripecia trágica, con independencia de que otros personajes, como el citado mensajero corintio, o la reina Yocasta, que con la intención de tranquilizar a su esposo consigue producir gran turbación en su ánimo, yerren con sus revelaciones en su pretensión de liberar a Edipo de sus cada vez más acuciantes sospechas ${ }^{25}$.

\footnotetext{
${ }^{25}$ No es extraño que Freud haya visto en el Edipo la constatación más hermosa de su teoría sobre el inconsciente y sobre el papel que las pulsiones del ello desempeñan en vida psíquica del sujeto. Edipo es literalmente arrastrado por su deseo inconsciente: se diría que ha hecho, desde la conciencia, todo lo posible para dar rienda suelta a su pulsión (sin quererlo y, naturalmente, sin saberlo). Es la gran paradoja que Freud, más interesado en ese momento en el complejo de Edipo que en la labilidad de las instancias psíquicas de sus tópicas, constata en la obra. Pero la oscilación entre el singular y el plural para referirse a la autoría del crimen de Layo muestra la emergencia en la conciencia de Edipo de un saber inconsciente que, finalmente, aflorará a la luz de la tragedia. Y es sumamente curioso que la insistencia del discurso en la cuestión del asesinato múltiple -se dice que Layo murió a manos de unos salteadores de caminos- se anude en la trama a partir de un lapsus del muy anciano Sófocles, un «fallo de guion» que no resta valor a la composición de la fábula: me refiero al momento en el que la reina, a instancias de Edipo, refiere que la noticia de la muerte de Layo llegó a Tebas cuando Edipo ya ocupaba el trono de la ciudad. No es un lapsus como otro cualquiera, al menos por dos razones: en primer lugar, porque entendemos ahora las razones que impulsaron al criado a mentir, puesto que ha visto con sus propios ojos el cumplimiento de la profecía, primero como testigo del crimen de Layo, a continuación como testigo del lugar que el asesino ocupa a su llegada en el trono de Tebas; puesto que él mismo ha desobedecido por piedad la orden de matar a aquel niño, miente, imputando la autoría del crimen a un grupo de bandoleros, y solicita el permiso de la reina para alejarse de la ciudad; en segundo lugar, y esto habría hecho las delicias de Freud, solo en este lapsus, desde el «inconsciente» del texto, emerge a la superficie textual la lógica edípica, según la cual el
} 
Según se deduce de la Poética, la peripecia no debería presentarse como un mero producto de la fatalidad, ni tendría que venir determinada por un encadenamiento de tipo: «culpa, por lo tanto, castigo»; en el primer caso, porque la inversión de la fortuna tendría un carácter de ultradeterminación y sería arbitraria desde el punto de vista de la estructura de la fábula, y, en el segundo, porque, o bien cuestionaría la excelencia de carácter postulada para el héroe trágico, en el caso de que la culpa proceda de su propia acción, o bien dejaría al que actúa al margen de sus actos. Es preferible, entonces, que el agente ponga en marcha la máquina infernal de la tragedia por algún error o hamartía, que alguna de sus decisiones propicie el infortunio, para que no sea mero producto del azar, y que no sean elecciones malvadas, merecedoras de castigo.

Según Aristóteles, la mejor peripecia trágica es la que lleva al héroe de la dicha a la adversidad (véase, sin embargo, infra, la valoración de Ifigenia entre los tauros como modelo de estructura catártica) por haber incurrido en algún error de carácter nocivo (bamartía) compatible con un carácter noble que haga posible la compasión del lector o espectador (13, 53a8-16). La hamartia, el yerro trágico que fundamenta la peripecia, no debe ser entendida como un fallo en sentido moral, sino más bien como un error de conocimiento u ofuscación mental momentánea; ha de ponerse por lo tanto en relación con la bybris (término que Aristóteles no emplea en Poética, aunque es de uso habitual en los textos de los trágicos) o desmesura, con el trágico desconocimiento y desafío de los límites humanos y con el posterior reconocimiento de los mismos. El propio concepto griego de hamartía tiene un sentido intelectual, desprovisto de connotaciones morales, y por eso, aunque la hamartía sea muy grave, como en Edipo, en nada empaña la nobleza de carácter del héroe. La compacta estructura de la fábula procede de un encadenamiento de sucesos que tienen su origen en un error: la peripecia ha de producirse, según Aristóteles, de un modo forzoso y verosímil, y es precisamente la hamartía la que justifica ese revés de la acción -ese «contra lo esperado» $(9,52 b)$ - que constituye la peripecia.

Lo que gira en la peripecia trágica no es en rigor la acción, sino el sentido que esa acción tiene para el agente, de manera que el conocimiento, y sus límites, ocupan un lugar central en la estructura trágica. Esos límites se pueden manifestar como ignorancia, y así ocurre en Edipo (ignorancia del parricidio, claro está, en ningún caso del homicidio), pero

deseo hacia la madre desencadena la hostilidad hacia el padre y no, como sucede en la tragedia, a la inversa: en Edipo rey, el regicidio y el parricidio traen como consecuencia el matrimonio con la reina viuda (en este caso, su madre).. En el lapsus, Edipo y la reina viven su idilio antes de que llegue a Tebas la noticia de la muerte del padre, en el orden que corresponde a la teoría freudiana del complejo. 
también es posible suponer que el campo semántico de la hamartía englobe errores resultantes de una desviación momentánea o temporal del propio carácter (ethos), como las motivadas por la fuerza de Eros (tan rentables en el cine: Max point, Herida) o por la ira momentánea, que no implica un carácter perverso. Ya hemos dicho que el asunto central de la tragedia está en la necesidad de descubrir cuál es el papel del hombre en un universo de valores ambiguos, en el que todas las normas se problematizan y en el que se ve obligado a tomar decisiones que lo implican a la vez como agente y como víctima, como sucede por antonomasia en la peripecia. La acción gira y, en ese revés, se torna contra el personaje que la ha emprendido; mas precisamente, el giro trágico revela el verdadero sentido de la acción y es este nuevo sentido, hasta ahora oculto para el agente, el que lo transforma en víctima de sus actos. El ejemplo paradigmático está en el Edipo de Sófocles, donde es imposible separar la peripecia de la anagnórisis que pone al descubierto la hamartía del rey tebano. Pero en este caso el desenlace es catastrófico y, en consecuencia, nos hallamos ante el modelo que Aristóteles describe en el capítulo XIII: el de un hombre [no ethos] intermedio, que no sobresale por su virtudy justicia ni cae en el infortunio por su bajeza o maldad, sino por algún yerro [hamartía], siendo de los que gozaban de gran prestigio y felicidad, como Edipo y Tiestes y los varones ilustres de tales estirpes $(13: 53 a 5-10)^{26}$.

Dada la excelencia del carácter trágico, y dada esa inversión paradójica de su elección en que consiste la peripecia, es lógico que Aristóteles no considere, en el tan discutido capítulo 13, la posibilidad de que la peripecia lleve a un hombre virtuoso de la adversidad a la dicha, ya que tal evolución haría suponer que no ha obrado con buena intención. Puesto que la peripecia consiste en un efecto paradójico de la elección, la intención tendría que haber sido mala para producir, como efecto contrario, un resultado dichoso. Sostenemos, pues, que: 1) dado que la tragedia presenta caracteres spondaios ${ }^{27}$, toda tragedia con peripecia debe presentar al héroe en una trayectoria que vaya de la dicha al infortunio, pues el héroe pretende lo mejor y, radicalmente equivocado (o sometido a impulsos que no

\footnotetext{
26 Sobre Tiestes, que en la tradición legendaria se presenta como un malvado sin fisuras, es posible que Aristóteles conociese alguna tragedia que hiciese comprensible su equiparación a Edipo en este pasaje de la Poética. Cfr. García Yebra (1972: nota 183).

${ }^{27}$ Spoudaios hace referencia al carácter trágico en oposición a phaulos, que define el ethos propio de la comedia. En este contexto, spoudaios, esforzado, frente a phaulos, que puede traducirse como vil, no significa exactamente que el carácter trágico sea noble, serio o grave, sino que indica el temple vital propio del hombre de bien, cuyo ánimo difiere, en sentido ético y político, del talante apocado y proclive al vicio del hombre vil. En el universo mítico, la areté heroica implica atributos como el poder, la inteligencia, la fuerza, la valentía, la fama, es decir, los que connotan la excelencia común a los caracteres trágicos. Cfr. García Bacca (1943: 51) y Weil (1961).
} 
puede dominar), alcanza lo peor: en eso, ya lo hemos dicho, consiste la peripecia. 2) Una tragedia con peripecia que describiese la trayectoria inversa supondría que el héroe obra con mala intención, premisa incompatible con las exigencias que el mismo Aristóteles postula para los caracteres trágicos. Queda, pues, el hombre intermedio. Es decir, se trata de la excelencia de un héroe que, solo en la medida en que desconoce, es sujeto del yerro trágico (hamartía). El héroe trágico es inocente, en sentido socrático: yerra porque ignora; aun más, persuadido a menudo de su propia excelencia, incurre en una desmesura (bybris) por la que debe pagar. El carácter noble, el rango y el valor que se exigen en el capítulo 15 de la Poética para los caracteres trágicos, están presentes en el hombre afectado por la peripecia; lo que le falta es la correcta interpretación de la situación, de su conducta y de sí mismo; el héroe es un ser humano limitado en su conocimiento, un hombre bueno que se equivoca: esa es la laguna de la excelencia de carácter.

Así se resuelve, si no nos engañamos, la contradicción entre la definición de las cualidades de los caracteres en el capítulo 15 y la consideración de la tragedia como mimesis de los mejores, y el «hombre intermedio» al que Aristóteles se refiere como modelo de carácter trágico en el capítulo 13 (53a8-11): en Edipo está presente esa excelencia de carácter, que se manifiesta en su voluntad de saber a cualquier precio y en sus nobles decisiones, pero su conocimiento es el de un «hombre medio» que interpreta erróneamente las circunstancias, desconoce a los demás y se desconoce a sí mismo, aunque, persuadido de estar en posesión de la verdad, incurra en hybris. El correlato de su hamartía es el terrible reconocimiento que desencadena el pathos trágico y se confunde, en perfecta unidad, con la peripecia: saber, llegar a saber (anagnórisis), es la verdadera peripecia: todo se revela ahora contra la intención y el sentido que había orientado las acciones perpetradas: el extranjero corintio es en realidad tebano; el descifrador de enigmas es un enigma para sí mismo y para cuantos lo rodean, hijo y esposo de la misma mujer, hermano de sus propios hijos; el salvador de su pueblo es en realidad la causa de sus males; el isotheos es un pharmakós, un hombre manchado que contamina a toda la ciudad. La tragedia del rey tebano queda así estructurada no como un proceso de acción, sino como un proceso de conocimiento, aunque es obvio, como señala Szondi (1978), que el proceso trágico no se agota en el análisis de lo que ya ha sucedido ${ }^{28}$.

Schiller supo captar bien el papel decisivo de la hamartía en la tragedia antigua: su

${ }^{28} \mathrm{Y}$, efectivamente, en el presente trágico Edipo, el salvador de la ciudad, amado y respetado por su pueblo, no solo pierde el trono de Tebas, sino a su esposa y madre, Yocasta, con cuyo alfiler se quita la vista y, en cumplimiento de su propio decreto, abandona la ciudad que lo ha exaltado al trono. 
cualidad básica no está ni en las calamidades del destino ni en las decisiones de la voluntad: está en los límites del conocimiento humano. Aristóteles no llega a expresarlo nunca con claridad, pero puede deducirse de la importancia que concede a la falsa interpretación en la estructura de la fábula, en Edipo, sobre todo, pero también en Antígona, cuyos personajes centrales se ofuscan y se obstinan en su particular percepción del conflicto que desencadena la tragedia ${ }^{29}$.

Pero sin duda fue Lessing el autor que, al subrayar el vínculo entre la peripecia y la hamartía, contribuyó con más acierto a la comprensión de la Poética. Es un hallazgo de madurez, posterior a su Dramaturgia, y se formula con precisión absoluta en la carta a Mendelssohn del 18 de diciembre de 1756: «Pero, ¿por qué esa hamartía como la nombra Aristóteles? ¿Quizá porque no sería perfecto sin ella y la desgracia de un hombre perfecto produce espanto? Ciertamente no. Yo creo haber encontrado la única causa correcta; es la siguiente: porque sin el error que precipita la desgracia sobre él, su carácter y su desgracia no constituirían un todo, porque el uno no se fundiría en el otro y pensaríamos cada una de esas dos partes separadamente». Efectivamente, creo que ahí está la clave para comprender, no solo la hamartía en su relación con la peripecia, sino el ethos en su relación con la acción.

Obviamente, Edipo es el modelo trágico sobre el que la Poética construye su teoría, pero, ¿qué sucede en las numerosas tragedias que describen una trayectoria inversa? Se podría decir que carecen de peripecia y, por lo tanto, quedan fuera de las posibilidades que Aristóteles examina en el capítulo 13. Es cierto que el término que se emplea a lo largo de todo este capítulo es metabolé, pero está fuera de toda duda que Aristóteles se refiere aquí a la peripecia, pues no solo habla de fábulas complejas (que podrían serlo únicamente con anagnórisis y pathos), sino que, suponiendo que hubiera que aplicar a todas las tragedias el único tipo de trayectoria aquí admitido (con desenlace necesariamente catastrófico), la mayor parte de las tragedias griegas quedarían fuera de tal consideración, cosa que obviamente no sucede en la Poética. En particular, el problema se plantea en las tragedias en las que Eurípides conduce a sus héroes hasta el borde mismo del precipicio para salvarlos a continuación, como por azar, cuando se hallan casi al límite de la catástrofe (la salvación en el último minuto del modelo clásico de Hollywood): Creúsa casi mata a su hijo; Ion casi mata a su madre; Ifigenia casi mata a Orestes, pero el reconocimiento del parentesco que los une evita el terrible lance y ésta es, para Aristóteles, la mejor disposición posible de los hechos para que se produzca

${ }^{29}$ Cfr.Hegel (1835: 532-541), Kommerell (1984) y Steiner, G. (1984). 
la catarsis (1454a5-10). Es evidente que la intervención del azar deja la acción fuera de cualquier control humano, incluso ya no es posible ni siquiera aceptar el destino impuesto por los dioses, como tantas veces sucede en Esquilo e incluso en Sófocles, pero Aristóteles refiere esta consideración a las tragedias con desenlace catastrófico, no a las que, como la Ifigenia ente los tauros, ofrece un final feliz y constituye, como hemos dicho, el modelo más adecuado para propiciar la catarsis del espectador. ¿Se trata de una tragedia con peripecia (en cuyo caso invalida la teoría expuesta en el citado capítulo 13) o se trata de una tragedia compleja en la que, aparte del sufrimiento inherente a toda fábula trágica, solo hay agnición, requisito que por sí solo satisface la definición aristotélica de la fábula compleja? Este es, sin duda, el caso de Ifigenia: hay anagnórisis, pero en ningún momento se produce un giro de la acción en sentido contrario a la proairesis de la protagonista que, desde el principio, deja claro que no oficia como sacerdotisa «voluntariamente», (ekon), sino akon, es decir, en absoluto de grado, por imposición de Artemisa, cuyos pensamientos torcidos reprueba (v. 380), aunque, dice, acaso los habitantes de esta tierra [los bárbaros tauros], homicidas como son, atribuyen a la diosa su maldad. Pues no creo que ninguno de los dioses sea malvado (vv. 385-390) ${ }^{30}$.

Es evidente que, para Aristóteles, hijo ya del nuevo mundo helenístico (y además de origen macedonio), el arte trágico y la purga catártica son dos cosas distintas, aunque no incompatibles: tanto el Ion como la Ifigenia entre los tauros, que elevan hasta cotas insospechadas la tensión emocional del espectador y propician su descarga en un final liberador, son melodramas de entretenimiento contra los que el de Estagira, a diferencia de Platón, no tiene nada que objetar. Acierta Collingwood (1938: 36) cuando dice que el análisis aristotélico de la tragedia ha de verse «no como una contribución a la teoría del arte, sino como una contribución a la teoría de la diversión», y de ahí, por ejemplo, la rentabilidad de la Poética como «manual para la escritura del guión», como yo misma he podido comprobar.

\section{SOBRE LA ANAGNÓRISIS}

La anagnórisis, agnición o reconocimiento, es el paso de la ignorancia al conocimiento, y ha de darse de un modo forzoso y verosímil. El reconocimiento puede producirse con relación a objetos, acciones o personas y, en este caso, puede serlo de uno

${ }^{30}$ Las citas de Eurípides corresponden a la traducción de Calvo Martínez (1978). 
mismo, de otro o bien un reconocimiento mutuo, para amistad o para hostilidad de los que se reconocen, para la dicha o para el infortunio (11, 52a30-52b8). La forma más perfecta de reconocimiento es la que va acompañada de peripecia, como la de Edipo (11, 52a32-33): en la medida misma en que Edipo se reconoce y es reconocido como asesino involuntario de su padre y como esposo involuntario de su madre, se produce la peripecia. El encadenamiento trágico es aquí perfecto: un error como causa trágica, una interpretación desmentida por la acción como proceso trágico: la anagnórisis deviene peripecia.

Según señala Aristóteles en el capítulo 16, el reconocimiento puede producirse de varias maneras; estas son, de peor a mejor:

- Por medio de señales corporales, congénitas o adquiridas, o bien a través de objetos añadidos al cuerpo. Es la forma más imperfecta de reconocimiento, sobre todo si las señales se muestran deliberadamente, como en Odisea XIX, cuando Ulises muestra su cicatriz a los pastores para que lo reconozcan. Es preferible, en este caso, que las señales sean descubiertas, como en Odisea XXI, cuando la nodriza, contra la voluntad de Ulises, advierte su cicatriz en el lavatorio (16, 54b19-21).

- Por artificio del poeta, como el reconocimiento de Orestes por Ifigenia, producido intencionadamente por las palabras que el poeta pone en boca del personaje, no por el desarrollo de la fábula; o el del Tereo de Sófocles, en el que Filomela manifiesta a su hermana Procne lo sucedido utilizando «la voz de la lanzadera» (bordando en una tela). En ambos casos la agnición se busca deliberadamente, y en esto se asemeja a la que se produce mediante señales corporales mostradas para tal fin (16, 54b35-36).

- A través de las emociones visibles que suscita el recuerdo, como sucede en los Ciprios de Diógenes cuando Teucro es reconocido al echarse a llorar ante el retrato de su padre, o en Odisea VIII, cuando Odiseo revela su identidad en el palacio de Alcínoo, emocionado al oír del aedo Demódoco el relato de la toma de Troya gracias a la argucia, que él mismo había ideado, del caballo de madera.

- Por medio de un silogismo, como el que está implícito en Coéforos de Esquilo cuando Electra deduce, al ver junto a la tumba de su padre un rizo de cabellos iguales a los suyos, el regreso de su hermano.

- A través de un paralogismo o falsa ilación de los lectores o espectadores, como la que debía de producirse en Odiseo falso mensajero (obra de la que nada sabemos) al pretender aquellos deducir, a partir del arco que portaba, la presencia de Odiseo, no siendo necesariamente correcta la mutua implicación entre Odiseo y el arco. 
- El sexto y mejor tipo de anagnórisis es aquel que se desprende de la fábula, el que se produce de forma verosímil y necesaria a través del encadenamiento de los hechos, sin necesidad de señales o signos materiales, como sucede en Edipo, de cuyas marcas (los «pies hinchados» por la violencia del abandono) nada se dice, o en Ifigenia entre los Tauros: Orestes reconoce a su hermana Ifigenia, que le ha entregado a Pílades una carta para que la haga llegar a su patria, Argos, porque al contarle de viva voz su contenido, por si la carta llegara a perderse, revela los datos que propician la anagnórisis. En ambos casos, lejos de revestir un carácter episódico, el reconocimiento desempeña una función estructural decisiva en la tragedia; en Ifigenia, porque todo se estructura y ordena en torno al reconocimiento mutuo de los hermanos que cambia de rumbo la evolución de la intriga de modo tal que Orestes, que iba a ser sacrificado por su hermana a la diosa Artemisa, huye con ella hacia la nave que los conducirá a tierra argiva; en Edipo rey porque la propia fábula se encadena como un proceso de reconocimiento de lo que ya se ha hecho y no admite vuelta atrás, como análisis del pasado (aunque, ya lo hemos dicho, el reconocimiento desencadena terribles consecuencias en el presente de la tragedia).

Aristóteles destaca el papel central del reconocimiento en la estructura trágica más perfecta, precisamente aquella en la que va acompañado de peripecia: lo esencial de la tragedia, como hemos dicho, está en el reconocimiento mismo de la hamartía y de la peripecia que de ella se deriva, es decir, en la revelación del error trágico y del alcance de sus consecuencias, en el hecho mismo de que las acciones perpetradas (como el homicidio y el matrimonio con la reina viuda en Edipo rey), se muestren ahora contra el sentido con el que habían sido realizadas (parricidio y regicidio, incesto), es decir, como peripecia: en Edipo en Colono, Edipo declara abiertamente que es inocente ante las leyes de la muerte de su padre, que sin conocerlo hizo lo que hizo, que «la ciudad misma fue la que [lo] enlazó en un matrimonio que, sin saberlo [él] era [su] ruina», que su hamartía no es más que el fruto de su ignorancia.

La agnoia, como veremos a propósito de los ethe, presenta grados y modalidades muy diversas, pero es indiscutible que el héroe trágico, para alcanzar la excelencia de carácter que Aristóteles reclama para los protagonistas de la tragedia, ha de reconocer el alcance y las consecuencias de sus acciones, condición asimismo indispensable para que se produzca el pathos trágico, la parte cualitativa esencial de la fábula. 


\section{SOBRE EL PATHOS}

La tercera de las partes cualitativas de la fábula es el pathos, una acción destructora $o$ dolorosa, como las muertes, tormentos, heridas y acciones de indole semejante (11, 52b11-13). El pathos es la parte esencial de la tragedia ya que, según Aristóteles, la peripecia y la agnición solo se dan en las fábulas complejas; sin ellas puede haber tragedia, pero no así sin pathos, que sería la cualidad indispensable de las fábulas simples. Aunque Aristóteles no lo aclara en la Poética, el pathos no se identifica siempre con el lance mismo, ya que existen tragedias en las que no se producen hechos de carácter cruento o sangriento, sino que ha de entenderse más bien como sufrimiento psíquico o moral -las graves desgracias morales de las que habla Goethe- producido por la inminencia de un mal antes que por el mal mismo, como se deduce de Retórica (II, 5, 1382a) y de la valoración que hace de la Ifigenia entre los tauros de Eurípides (en la que el reconocimiento entre los hermanos evita el sacrificio de Orestes) como modelo de estructura catártica $(14,54 a 5-8)$.

Cuando el pathos culmina en un hecho de carácter sangriento es preferible que este se produzca fuera de la vista del espectador, ya que el temor y la compasión deben proceder del sufrimiento más que de sus manifestaciones externas, como sucede en Edipo rey, tragedia cuyos lances, o bien pertenecen al pasado, como el asesinato de Layo, o bien tienen lugar en el interior de palacio, fuera de escena, y se confían al relato de un mensajero: Oh cosas, etc. Adviértase, por lo demás, que el verdadero pathos trágico de la obra no procede del hecho de que Edipo se quite la vista o Yocasta se ahorque como reacción ante un sufrimiento insoportable: lo verdaderamente patético es saber, reconocer la bamartía y sus terribles consecuencias.

Según Aristóteles, es preferible que el lance patético se produzca entre amigos, aliados o miembros de la misma familia, pues si un enemigo se enfrenta a su enemigo nada inspira compasión a no ser el lance mismo, mientras que cuando estas acciones se dan, o están a punto de darse, entre deudos o allegados, resultan impresionantes por su intensidad y rareza (14, 53b16-23): la familia es para Aristóteles el ámbito trágico por antonomasia; de hecho, el mythos de cuyo repertorio se provee la tragedia se refiere a unas cuantas familias a quienes aconteció producir o padecer sucesos espantosos (13, 53a8-21).

Es posible que el enfrentamiento se desarrolle con pleno conocimiento del vínculo de sangre entre los personajes o que los personajes lo ignoren. Aristóteles distingue aquí cuatro posibilidades en el juego de interrelaciones entre el conocimiento del parentesco y la 
ejecución del lance. A la luz de sus opiniones acerca de la ignorancia del alcance de la acción como núcleo por excelencia de lo trágico, es lógico que, de las cuatro posibilidades que el filósofo distingue, las más trágicas sean precisamente aquellas en las que el desconocimiento produce, o está a punto de producir, un mal irreparable. De peor a mejor, las posibilidades que distingue Aristóteles son las siguientes (14, 53b27-54a8):

- Estar a punto de consumar el crimen con pleno conocimiento del vínculo de sangre y no hacerlo es la peor situación de todas, pues, siendo repulsiva (dado que se conoce el vínculo), no es trágica, ya que le falta lo patético. Es el caso de Hemón, a punto de matar a su padre en Antígona ${ }^{31}$.

- Consumar el crimen con conocimiento del vínculo familiar ocupa el segundo puesto. Sucede así en la Medea de Eurípides, en la que la madre asesina a sus hijos sabiendo que lo son.

- Que el conocimiento del vínculo sea posterior al crimen, como en Edipo rey de Sófocles, es una fórmula superior, pues lo trágico estriba en ser consciente a posteriori de una acción que, perpetrada en la ignorancia, resulta irremediable.

- Que, estando a punto de consumarse el lance, el reconocimiento del parentesco impida que se lleve a término, como en el caso de Ifigenia ante su hermano en la Ifigenia entre los tauros de Eurípides. Esta cuarta posibilidad, al contrario que la primera, no tiene nada de repulsivo, pues Ifigenia ignora el vínculo, y resulta sin embargo plenamente catártica.

No es extraño que Aristóteles valore esta última modalidad como la más catártica, pues en ella la inminencia del lance -la muerte de Orestes- provoca en el espectador (o lector) una situación de sufrimiento emocional intenso que, afortunadamente resuelta, conduce al alivio final. Desde este punto de vista, resulta comprensible que Aristóteles componga la Poética conforme a un presunto canon de perfección subyacente, que sería Edipo rey, que solo en este aspecto -el efecto catártico- resulta inferior a la modalidad que presenta Ifigenia entre los tauros. Esta valoración es un testimonio elocuente de la presencia en la Poética de una teoría del entretenimiento, la vinculada a la catarsis, al efecto trágico predeterminado para la composición de la fábula, compatible con el valor estético de la obra, pero no equiparable al mismo. Efectivamente, ya lo hemos dicho, la Ifigenia entre los tauros es un melodrama brillantemente resuelto, pero carece de la intensidad trágica y del alcance de Edipo

\footnotetext{
${ }^{31}$ En realidad, Hemón se enfrenta a Creonte en un momento de ira y a continuación dirige la espada contra sí mismo. Ya Batteux había observado que no se trataba aquí de perpetrar un crimen contra su padre, y finalmente no llevarlo a cabo, sino de una reacción emocional explicable por la situación desesperada en la que se halla el personaje. Cfr. García Yebra (1974: nota 203).
} 
como forma de conocimiento del ser humano, de su fragilidad y de sus limitaciones. Sin embargo, el desenlace de la Ifigenia es más catártico que el de Edipo rey, pues presentando ambas obras al receptor la oportunidad de esa identificación doble que define la catarsis (compasión por el inocente, temor por el semejante), la tragedia de Edipo se cierra en una situación de angustia que, lejos de producir una purga de tales afecciones, las abandona en una cota máxima, que no cederá hasta la prosecución de la intriga en Edipo en Colono.

\section{SOBRE LOS CARACTERES}

Las escuetas y controvertidas observaciones aristotélicas sobre los caracteres de la tragedia han de ser interpretadas a la luz de su Retórica y de sus Éticas, inseparables de su Politica: la Ética a Eudemo, la Ética a Nicómaco y la llamada Gran Ética, la Magna Moralia, cuya autoría es cuestionada por algunos helenistas Fue Jaeger, como es sabido, el autor que más atención dedicó a la datación de las Enciclopedias y de los tratados exotéricos de Aristóteles, pero los numerosos estudios emprendidos con posterioridad a la publicación de su Aristóteles (1923), entre ellos el temprano ensayo de Gadamer (1928) publicado en Hermes, coinciden en que la Eudemia es anterior a la Nicomaquea y esta última posterior a Retórica, más atenta a establecer los tipos genéricos (del auditorio), a los que dedica el capítulo 2 del Libro II que a los caracteres en sentido estricto. Aquí señala que el ethos constituye una disposición estable del psiquismo o talante determinado por la edad y los bienes que proceden de la fortuna, como la nobleza de estirpe, que Aristóteles distingue de la nobleza de carácter (1390b20-25), la riqueza, el poder y la buena suerte, que conforman «un modo de ser» en el que el auditorio puede reconocerse. En Ética a Eudemo (II 2, 1220a39-65) relaciona los caracteres con los hábitos, en la línea de la doctrina desarrollada por el ultimo Platón (por ejemplo, Leyes VII, 518e), aunque va más allá al afirmar que es posible por medio de ellos crear una segunda naturaleza.

En Ética a Nicómaco, se halla el esfuerzo analítico más profundo para distinguir las diferentes modalidades de la acción, sobre todo en el Libro III, que se abre con el propósito de definir lo voluntario (ekousion) y lo involuntario (akousion) en un momento en el que la cultura griega todavía carecía de términos apropiados para referirse a la esfera de la voluntad humana: son involuntarias, afirma, las cosas que se hacen por fuerza o por ignorancia, pues es claro que el agente no es en estos casos dueño de sus actos (1109b30-35; 1110a), y es 
voluntario «aquello cuyo principio está en uno mismo y que conoce las circunstancias concretas de la acción»(1111a22-24). En principio, podría parecer que los términos ekon/akon designan algo parecido a lo que actualmente entendemos como voluntario o involuntario, y así suelen traducirse ${ }^{32}$, pero inmediatamente advierte Aristóteles que «de lo voluntario (ekousion) participan también los niños y los otros animales» (1111b5), y no han de considerarse involuntarias las cosas que se hacen por coraje (ira) o por apetito (se refiere aquí a las pasiones irracionales). En un sentido similar, en el Libro III De anima y en el De motu animalium, refiere las nociones de lo ekousion y lo akousion a las acciones y movimientos del animal: mientras que lo ekousion se vincula a la órexis, al deseo, y por lo tanto a lo que los animales realizan para alcanzar un objeto (como el alimento o la satisfacción sexual), lo akousion responde exclusivamente a las necesidades fisiológicas que no implican al agente (como respirar o dormir). Está claro, por lo tanto, que ekon/akon no equivalen a lo que entendemos como voluntario o involuntario, sino más bien a lo que se hace de grado o no de grado, aspecto que efectivamente comparte el comportamiento humano con el de los animales (y así el acto sexual puede realizarse de grado en ambos casos, pero nunca diríamos que voluntariamente para referirnos al segundo de ellos). Y, efectivamente, en el capítulo 2 del Libro III de la Nicomaquea, introduce un concepto y un término, proairesis, de escasa utilización y sentido muy difuso hasta ahora, para referirse a la acción realizada tras deliberación y decisión, es decir, la que implica el mayor grado de compromiso y conciencia del sujeto: «la elección (proairesis) es manifiestamente algo voluntario (ekousion), pero no se identifica con lo voluntario (ekousion), que tiene más extensión»: de lo voluntario (ekousion), ya lo hemos dicho, participan también los niños y los otros animales, «pero no de la elección (proairesis), y a las acciones súbitas las llamamos voluntarias, pero no elegidas» (1111b5-10). La elección, en efecto, «no es algo común también a los irracionales, pero sí el apetito y el impulso» $(1111 \mathrm{~b} 12)^{33}$.

Es, pues, en la proairesis, y no en el campo de oposición ekon/akon, donde ha de hallarse la clave interpretativa más adecuada para la definición de los caracteres, pues como señala el mismo Aristóteles, son nuestras elecciones íntimas las que, mejor que los actos

\footnotetext{
32 Así los traducen, de hecho, Araujo y Marías (1989).

33 No entro aquí a valorar el interesantísimo problema que suscita la adquisición de la proairesis en la evolución del niño y en su transición a la vida adulta. Para un análisis de esta cuestión, puede verse Nussbaum (1986: 366 y ss). Incluye referencias a las tesis de T.H. Irving sobre la noción de responsabilidad y sus implicaciones en la valoración ética de los comportamientos humanos (Rorty 1992: 117-156).
} 
exteriores, permiten juzgar nuestro carácter y «por elegir lo que es bueno o malo tenemos cierto carácter» (1112a). Por eso, precisamente, queda excluida del capítulo XIII la posibilidad de un final feliz en las tragedias con peripecia: efectivamente, habría que suponer que el héroe, pretendiendo lo peor, ha obtenido lo mejor, premisa que invalida la bondad de carácter que requieren los personajes trágicos, bondad compatible con la hamartía, por muy grave que sean sus consecuencias: Cuando se obra [...] a impulsos de la ira o de las demás pasiones que son inevitables o naturales en el hombre, señala en el Libro V de la Nicomaquea, los autores no son por ello injustos ni malos, porque el daño no tiene por causa la maldad; pero si lo hacen proponiéndoselo (proaireseos), son injustos y malos (1135b20-25).

Es obvio que la proairesis implica al intelecto, a la actividad racional del sujeto, pero no es independiente de la parte apetitiva del alma, de manera que en ella se implican el deseo y el pensamiento. Se entiende, entonces, el sentido de la hamartía y su decisivo papel en la conformación del carácter trágico: es un error de conocimiento, en efecto, pero en absoluto ajeno al arrebato de la pasión y a la obstinación que ofusca al personaje y lo conduce hacia el precipicio. Ya hemos dicho que el Eteocles de Los siete contra Tebas es el prototipo del hombre de Estado, el que dirige el país de acuerdo con los valores de la nueva polis: confía la defensa de la ciudad a una buena estrategia guerrera -Dicen que cuando una ciudad es conquistada los dioses salen de ella y la abandonan (vv. 215-220)- y censura los excesos emotivos de la religiosidad femenina - ¿Es ese el mejor modo de salvar la ciudad e infundir ánimo a un ejército que está sitiado? ¿Andar gritando y vociferando postradas ante las imágenes de los dioses que son protectores de nuestra ciudad? (vv. 180-185). Pero sobre él pesa la terrible maldición de Edipo, que desata su furia destructora y lo empuja a enfrentarse con su hermano en la séptima puerta: en la aceptación del destino impuesto reside la grandeza de su carácter y, paradójicamente, es ahí donde se manifiesta su libertad y la de tantos héroes esquíleos. Ate-cantará el Coro- ha erigido un trofeo en la puerta en que se batieron y, vencedora de ambos hermanos, se aplacó la deidad (vv. 955-960) ${ }^{34}$.

En Agamenón, el protagonista se ha visto obligado a actuar por coacción externa: la excelente párodos del Coro de ancianos argivos relata su terrible elección entre dos mandatos divinos incompatibles - uncido al yugo de la ineluctable necesidad (vv. 218-219)- y su impía y sacrílega decisión de sacrificar a su propia hija. En cierto modo, la muerte de Ifigenia aparece como una fatalidad, como un «mal menor» impuesto por la necesidad de salvar a la escuadra y llevar a cabo su empresa guerrera - ¿Qué alternativa está libre de males? (vv. 211)-, pero una vez que ha

${ }^{34}$ Las citas de Esquilo corresponden a la traducción de Perea Morales (1986). 
tomado esa determinación, la desea con intensa vehemencia, con la osadía que a los mortales enardece la funesta demencia, consejera de torpes acciones, causa primera del sufrimiento (vv. 220-225). El ethos de Agamenón se revela monstruoso porque ha elegido ekon, de grado, el sacrificio de su hija, no porque lo haya decidido voluntariamente. Sin embargo, el nexo entre su carácter y su acción se manifiesta en el momento en el que pone sus pies sobre la alfombra púrpura que Clitemnestra ha dispuesto para su recibimiento (vv. 810-974): en ese momento descubrimos que la vida y el amor de su hija no tienen para él el mismo valor que la derrota de los troyanos, que ha preferido la victoria en la guerra a la philia familiar, que ha elegido según su deseo y ha actuado con la vanidad arrogante de los vencedores, con la bybris impía que se volverá contra él a manos de Clitemnestra. El asesinato de Agamenón no es ajeno a la maldición de los Atridas, pero es él, con la inmolación de su propia hija y con su nefasto orgullo, quien echa a andar la maquinaria de la tragedia.

El crimen de Clitemnestra no difiere sustancialmente. La vemos actuar contra el esposo premeditadamente y con la complicidad de Egisto, sin coacción aparente: es una mujer herida por el sacrificio de su hija, no tanto en sus sentimientos maternales (que no parece tenerlos, al menos con el resto de sus hijos) como en su orgullo de esposa y madre ultrajada en beneficio de Helena y Menelao, abandonada durante diez años por una guerra que el Coro condena, y humillada por la llegada de Casandra como concubina de su esposo. Ella actúa deliberadamente y de grado (ekon), pero la ambigüedad de la decisión trágica es en cierto modo la misma: la acción emana del carácter -ya sea por impulso, como en Agamenón, o por maquinación, como sucede aquí-, pero el más allá divino sigue estando presente en el seno de la decisión trágica: en el momento mismo en el que la reina se regocija de su hermosa obra, en el canto amebeo (alternado) entre el coro y Clitemnestra, atribuye la paternidad del crimen perpetrado por sus manos a Ate y a la Erinia, al terrible daimon vengador de Atreo: Afirmas tú que esta obra es mía y que soy la esposa de Agamenón. No es así, sino que bajo la forma de la mujer de este muerto, el antiguo, amargo genio, para tomar venganza de Atreo-aquel execrable anfitriónha hecho pagar a éste y ha inmolado a un adulto en compensación de unos niños (vv. 1500-1505) ${ }^{35}$.

En Coéforos, también Orestes vacila antes de dar muerte a su madre-Oh, Pílades, ¿̇qué hacer? ;Ella es mi madre! ¿No me atreveré a matarla? (vv. 895-900)-, pero el hado dirige su brazo a

\footnotetext{
35 Ella misma es la venganza de la antigua mancilla de la casa de Atreo, como lo será Orestes hasta que su absolución ponga fin a la cadena imparable de violencia desatada por la maldición que pesa sobre su linaje. Cfr., por ejemplo, Girard (1972). Es cierto que Clitemnestra todavía muestra la rigidez psicológica que caracteriza a los personajes del teatro de Esquilo, pero, frente a lo que cree Jacqueline de Romilly, ya manifesta los motivos humanos que la impulsan a actuar contra Agamenón: se lamenta de su larga ausencia, del sacrificio de su propia hija, de la osadía del esposo al presentarse en compañía de su concubina. Cfr. Romilly (1970: 40).
} 
la venganza (vv. 910-912). Antes de perder la razón, proclamará que ha actuado no sin ley y que fue Loxias el filtro instigador de tanta audacia (vv. 1028-1030). A diferencia de su madre, una especie de Lady Macbeth que nunca llega a experimentar dolor por el esposo ni arrepentimiento por su abominable crimen (solo temor a la venganza subterránea a manos de su hijo, atormentada por el sueño profético), Orestes declara el sufrimiento que le producen los crímenes de su estirpe cuando siente sobre él la no envidiable mancha de esta victoria mía (vv. 1015-1020) y su decisión de exiliarse del país en el que ha perpetrado su matricidio.

No hay, pues, en Esquilo, un ethos al margen del poder divino. La acción trágica se sitúa a la vez en el hombre y fuera de él: el mismo personaje aparece como agente, y por lo tanto como fuente y causa de lo que hace, y como alguien poseído por ese daimon que lo arrastra y lo sobrepasa. En el interior de cada protagonista volvemos a encontrar la misma tensión que la tragedia establece entre el pasado mítico y el nuevo orden de la ciudad: el mismo personaje aparece como el héroe de otro tiempo, atado a las antiguas potencias divinas y a las maldiciones que pesan sobre las sagas familiares, y como un ciudadano ateniense obligado a actuar y a pensar de acuerdo con otras pautas ${ }^{36}$.

Cuando vemos a Edipo cargar con la responsabilidad de su terrible crimen, no se nos escapa que es inocente en sentido socrático, que ha emprendido acciones cuyo verdadero sentido ignoraba y que ahora, al volverse contra él, revelan su auténtica significación. Él ha actuado, pero ¿hasta qué punto se puede decir que es dueño de sus acciones? El texto repite dos veces una oposición que tiene interés para comprender el papel del ethos en la acción trágica: se trata de la oposición entre los actos realizados akon (a pesar de uno mismo) y los realizados ekon (de grado). Ya hemos dicho que no son sinónimos de involuntaria o voluntariamente, porque no existe en el horizonte de la tragedia un concepto similar al de la voluntad (Ética a Nicómaco, 1111a25-27 y 1111b7-8), pero podrían delimitar el campo de lo causado por un daimon y lo escogido por uno mismo. Así, las adversidades de Edipo son akonta, sufridas a su pesar, pero el daño que se inflige a sí mismo cuando se revienta los ojos es ekon, es el fruto de su decisión, como dice el servidor que narra el cruento suceso al público:

\footnotetext{
${ }^{36}$ Esta tensión entre ethos y daimon nunca llega a ser enteramente eliminada de la tragedia; en Esquilo, el más optimista de los trágicos, la victoria del ideal cívico sobre las fuerzas del pasado no liquida totalmente las contradicciones entre los dioses antiguos y los nuevos, entre el pasado de los linajes heroicos y el presente de la ciudad: la integración de las Erinias en el orden de la ciudad, al final de la Orestea, crea un equilibrio no exento de tensiones: solo el voto de Atenea evita la condena del matricida, vengador de su padre: Orestes será absuelto legalmente del asesinato, pero esto no lo convierte en inocente ni justifica su crimen. Cfr. Aristóteles, Problemata, $29,13$.
} 
un mal no sufrido a su pesar (akon), sino cometido de grado (ekon). ¿Podría, entonces, trazarse con nitidez la línea que separa en el drama causalidad humana y causalidad divina? No. Cuando Edipo sale del palacio, tanto las palabras del coro como las del propio rey borran los límites entre el ethos y el daimon: la iniciativa humana y la causalidad divina se funden en un lenguaje que oscila entre el terreno de la acción y el de los sufrimientos impuestos por el destino: ¿Qué cosa terrible has hecho, qué daimon te ha empujado?, pregunta el coro. Es Apolo el autor de mis sufrimientos atroces, pero nadie me ha herido con su propia mano, sino yo mismo, desventurado, responde Edipo (vv. 1327-1332).

Incluso en Eurípides, cuyos personajes no son a menudo víctimas de ignorancia, está presente esa fuerza brutal de la pasión que los empuja a las peores acciones: al final de la Medea, Jasón atribuye el comportamiento de su esposa a un alástor, al genio vengador del crimen sin expiar de su hermano; los espectadores de la tragedia, al menos las gentes educadas, sabían que esta forma de hablar era ya simbólica, porque el daimon había perdido su existencia sobrenatural, pero, aun dentro del hombre, su poder resultaba igualmente misterioso y aterrador: Sí [exclama Medea poco antes de consumar la muerte de sus hijos], conozco los crímenes que voy a realizar, pero mi pasión es más poderosa que mis reflexiones y ella es la mayor causante de males para los mortales (vv.1078-1081). Gran parte de la intensidad trágica de Eurípides procede de su peculiar manera de mostrar al hombre frente al problema del mal, no ya como algo que procede de fuera, sino como parte de sí mismo: ni cometen errores, ni atribuyen sus males a alguna fuerza maligna externa: su conducta es fruto de la fuerza irracional de la pasión, una pasión que Eurípides ha elevado a la condición de enemigo interno del hombre y que, a diferencia de la antigua até, no nubla el conocimiento, aun siendo más poderoso que él: aunque el Hipolito presente a Afrodita como causa del desdichado amor de Fedra ${ }^{37}$, ella misma confiesa a las mujeres del Coro que los mortales no obran de la peor manera por la disposición natural de su mente, pues muchos de ellos están dotados de cordura. No; hay que analizarlo de este modo. Sabemos y comprendemos lo que está bien, pero no lo ponemos en práctica (vv. 377-382). Es evidente que estamos lejos de la concepción de la virtud sostenida por Sócrates, para quien obrar mal implica necesariamente el desconocimiento del bien, pero la impotencia moral de la razón es sin duda uno de los aspectos que hacen de Eurípides el más trágico de los poetas, precisamente en las obras de plenitud que, como Medea o Hipólito, conducen a sus

\footnotetext{
${ }^{37}$ La nodriza compara a Fedra con una yegua agitada por el movimiento de las bridas, presa del extravío de un dios que ha ofuscado su mente. Está claro, sin embargo, que la pasión humana es el asunto central del drama de Eurípides, un hombre ilustrado que ya no creía en absoluto en las divinidades tradicionales. Sobre el papel de Afrodita y Artemis, puede verse Lesky (1977).
} 
protagonistas a un final catastrófico.

El carácter trágico no puede definirse sin tener en cuenta esta dualidad que lo constituye y que planea constantemente sobre la acción; se podría decir que es incluso el rasgo definidor de la tragedia antigua, centrada, como hemos visto, en la necesidad de esclarecer el papel que el agente humano desempeña, a medio camino entre la decisión y el destino, en sus propias acciones. Un papel que, ya lo hemos dicho, no es ajeno a la constitución de unas normas jurídicas capaces de articular las antiguas formas del pensamiento religioso, siempre vivas en los mitos heroicos, con las exigencias de la nueva polis.

La filosofía moral aristotélica obedece a un propósito que la tragedia plantea, pero no resuelve: se trata de fundar la responsabilidad subjetiva del agente, de distinguir entre el acto realizado de grado y el realizado a pesar de uno mismo (ekon/akon), de atender a las intenciones del que actúa y a las condiciones internas de la acción. Pero la tragedia todavía muestra la confusión entre los diferentes niveles de la acción (en el mito y en la nueva polis), muestra que el sujeto no puede afirmarse todavía en su plena dimensión de agente, muestra que aún permanece atado al pasado, aunque ya asuma la responsabilidad de los actos que ha realizado sin verdadera intención (puesto que no ha decidido por sí mismo, sino por coacción o ignorando el verdadero sentido de su acción), como sucede en Edipo, que se declara inocente ante los dioses, pero acepta el castigo que él mismo, como soberano de Tebas, ha decretado para el asesino de Layo. Y muestra también, en las tragedias de Eurípides, que la razón no basta para garantizar una conducta buena, que la parte apetitiva del alma, a diferencia de lo que creía Platón, no podía subordinarse de una manera simple al conocimiento.

\section{SOBRE LAS CUALIDADES DE LOS CARACTERES}

Hemos visto que Aristóteles define el carácter como «aquello que manifiesta la decisión [proairesis], es decir, qué cosas, en las situaciones en que no está claro, uno prefiere o evita» (6, 50b9-11). Esta posición electiva del hombre ante las cosas no debe entenderse nunca separada de los factores que, al matizarla, la vuelven plenamente trágica: de un lado, las limitaciones del saber humano, el radical desconocimiento (agnoia) que lleva al héroe a equivocarse (hamartía) con arrogancia (bybris); del otro, ya lo hemos dicho, su inapelable 
sometimiento a los designios de la Moira, de ese destino que juega con el hombre y burla sus intenciones al desatar, a partir de aquellas, una cadena de efectos paradójicos (peripecia): el daimon y el ethos conviven en el personaje trágico y conforman esa peculiaridad irrepetible que define la tragedia antigua. Por esta razón, las cuatro cualidades que la Poética atribuye a los caracteres trágicos en el capítulo 15, establecidas en función de su adecuación a la totalidad estructurada que constituye la fábula y a la finalidad catártica propia de la tragedia, han de interpretarse necesariamente a partir de esta dualidad que pone en juego el pasado heroico del mito y el nuevo orden político y ético de la ciudad ateniense. Dicho rápidamente, estamos lejos del sujeto responsable y libre, que ha actuado de manera voluntaria y consciente, y estamos lejos también de la noción de carácter en el sentido psicológico moderno ${ }^{38}$, aunque en Eurípides ya se puede apreciar una mayor complejidad de los personajes, justamente cuando las acciones se van vaciando de sentido (como sucede en la tragedia moderna, y de manera paradigmática, en el Godot, por ejemplo: ya no hay nada que hacer, ya no hay decisiones que tomar, se trata más bien de matar el tiempo: esto no tiene sentido pero hay que seguir adelante: la errancia, el vagabundeo).

La primera exigencia es que los caracteres representados por la tragedia sean buenos (chresta). El carácter, precisa Aristóteles, será bueno si la decisión (proairesis) es buena, y viceversa $(15,54 a 16-19)$. Contra las posiciones tradicionales que han tratado de asimilar la «bondad» al rango social del personaje, a su excelencia en el sentido poético, incluso a la extremosidad de su talante vital (sea bueno o malo), entiendo que se trata de una bondad en sentido moral, requisito indispensable para que la compasión del espectador pueda suscitarse. La definición misma de la tragedia como imitación de los mejores, de los que sobresalen por su virtud, ratifica esta interpretación, puesto que Aristóteles utiliza aquí un término inequívoco, areté, y su opuesto, kakía, para referirse al carácter de los peores, propio de la comedia (2, 48a2-4, 48a17-19). Además, Aristóteles señala, en el capítulo 13, que no provoca compasión ni temor que un malvado pase de la dicha a la desdicha, ni mucho menos de la desdicha a la dicha -pues esto es lo menos trágico que pueda darse. Únicamente el sufrimiento de un hombre bueno puede provocar en el espectador esa moción com-pasiva del ánimo que es condición de la catarsis. Ahora bien, la bondad moral que Aristóteles establece como requisito del carácter trágico no se contradice con su condición de personaje intermedio (13, 53a8-11): una razón estructural obliga al poeta a presentar como sujeto de la 
peripecia un carácter construido según una fórmula de bondad/hamartía indisociables, pues si un héroe moralmente bueno no se equivocase no habría tragedia: es exactamente en la relación entre la bondad de la proairesis y lo inevitable de la hamartía donde el eje trágico se sitúa. La tragedia, desde el punto de vista del carácter moral del personaje, consiste en errar sin pretenderlo; aún más, errar en la fe de estar obrando bien y cometer ese error apasionada y orgullosamente. Ese talante desmesurado que caracteriza la actuación del héroe trágico (pensemos en la obstinación de Antígona, en la inconsciente arrogancia de Edipo...) contribuye de forma decisiva al efecto trágico. Más allá, lejos de empequeñecerse en el reconocimiento de sus errores, los caracteres trágicos manifiestan su verdadera grandeza ante la desgracia.

Ya hemos dicho que el yerro trágico ha de ser atribuido preferiblemente al conocimiento, pero hemos de convenir en que las pasiones, en la medida en que no quedan excluidas de la proairesis, son el desencadenante de la mayor parte de las tragedias, sobre todo en Eurípides, en el que la até no procede de instancias ajenas a los personajes, sino de la fuerza de sus propias pasiones, que son incapaces de controlar racionalmente. Es evidente, por lo demás, que Edipo rey es el modelo que Aristóteles prefiere para formular su teoría de la tragedia, difícilmente aplicable a otras tragedias, y en particular a las de Eurípides, cuyos protagonistas han perdido la dimensión heroica y solemne de sus prototipos míticos: Medea es una mujer herida por la traición de Jasón, incapaz de controlar su pasión y plenamente consciente de su crimen; la Fedra de Hipólito sucumbe al amor y, sirviéndose del engaño, arrastra al joven en su caída, pero ni la pasión amorosa de Fedra ni la patológica castidad de Hipólito, aunque asociadas al molde clásico de la bybris y a la presencia en el texto de Artemis y Afrodita, tienen nada que ver con la dimensión superior en la que se inscriben los conflictos de los personajes de Sófocles. La diferencia se observa bien si comparamos la Electra de Sófocles con la de Eurípides, muy cercanas en el tiempo: ambas respetan el mito, pero los personajes de Eurípides son seres humanos inseguros y abrumados por sus desgracias, desprovistos de carácter heroico y, por tanto, víctimas de una situación que ahora se revela absurda. Incluso en tragedias como el Heracles, que recuerda al Ayante sofocleo, se advierte esa humanización de los personajes que caracteriza al último de los trágicos: aconsejado por Teseo, renuncia al suicidio y acepta continuar su vida con el recuerdo amargo de haber dado muerte a su mujer y a sus hijos. Es un buen ejemplo de cómo se ha producido el paso de la cultura aristocrática de la vergüenza a la cultura de la culpa: Ayax solo encuentra en la muerte una salida a su deshonra, porque su dignidad heroica no le permite enfrentarse 
a una vida oscura, mientras que Heracles es capaz de seguir viviendo abrumado por el dolor de su terrible acto.

El sentido moral que hemos atribuido a la bondad de carácter no ha de ser interpretado, como es obvio, desde un horizonte ético cristiano, que dejaría fuera de esta consideración a la mayor parte de los protagonistas de la tragedia, incluido Edipo, que no es regicida ni parricida conscientemente, pero sí plenamente responsable de homicidio. Se trata se una bondad que en el mundo griego tiene todavía connotaciones éticas heroicas y políticas y, como se desprende de la distinción entre tragedia y comedia, opone las acciones del hombre spoudaios, el hombre de bien, a las del phaulos, proclive al vicio, que define el ethos propio de la comedia.

La segunda cualidad es que sean adecuados o apropiados. Entendemos por adecuados los caracteres que, en el caso de que la fábula verse sobre un mythos consagrado, se adaptan a la imagen general que el virtual receptor se haya hecho de los mismos. No se deben contradecir, por ejemplo, los caracteres tradicionalmente asumidos de Antígona o Edipo. En el caso de que la fábula fuera invención del poeta, los caracteres deberían adaptarse al régimen de expectativas previsto por la opinión común $($ doxa): por ejemplo, según señala Aristóteles $(15,54 a 23-25)$, no resulta apropiado que una mujer sea varonil o temible, y el poeta no debería, por tanto, si él mismo fuera el inventor de la historia, construir un carácter femenino de índole semejante. Sin embargo, en el caso de que se limite a reelaborar un mythos preexistente, la verosimilitud inherente al mito le permitiía dibujar un carácter femenino que, como el de Medea, frenético y «viril», solo por su preexistencia en la memoria colectiva se adecua a las expectativas de verosimilitud. De hecho, muchas protagonistas del teatro griego son absolutamente inadecuadas desde el punto de vista de las cualidades que corresponden al carácter femenino doxático en el horizonte cultural de la época (Antígona, Clitemnestra, Medea, etc.). Su pertenencia al orden mítico las aprioriza como verosímiles.

La adecuación doxática es visible, sobre todo, en la caracterización de personajes secundarios, como el vigía que aguarda la señal de la antorcha en la azotea, en el Prólogo de Agamenón, la nodriza de Orestes, en Coéforas, el guardian de Antígona, el criado que miente en Edipo, etc.

La tercera exigencia es la semejanz̧a, que, según señala Aristóteles, no es lo mismo que el carácter bueno y adecuado. Esta exigencia del carácter trágico, sobre la que nada más precisa, ha sido interpretada tradicionalmente en el sentido que nosotros hemos atribuido al carácter adecuado, y entendida, más precisamente, como fidelidad a los tipos consagrados por 
la tradición. Desde mi punto de vista, la exigencia aristotélica de la semejanza adquiere sentido por su relación con las condiciones de la catarsis: el temor por un semejante, que está en correlación con la compasión por el inocente. Semejante, entonces, a la naturaleza humana, puesto que la identificación entre el héroe y el receptor, que es condición sine qua non de la catarsis, únicamente es posible con respecto a un semejante, a un constructo poético cuyo carácter aparece tipificado de tal modo que su destino trágico (de acuerdo con la universalidad que la actividad mimética confiere a la creación poética) es comprensible y concierne al común de los mortales. La semejanza de carácter implica que el espectador ideal de la tragedia puede sentirse compadecido ante la inocencia del héroe-que no es merecedor de tales desgracias-, y temeroso ante la posibilidad de hallarse en su lugar. El personaje trágico debe ser semejante a la naturaleza humana en lo que aquélla tiene de bueno y de falible, como el mismo Aristóteles apunta en el controvertido capítulo 13, en el que excluye de la tragedia a los hombres perfectos sea cual sea el desenlace de la misma (eliminando, dicho sea de paso, los dramas cristianos de santos y la propia tragedia de Cristo, como vio muy bien Corneille).

La cuarta y última exigencia es que los caracteres imitados sean coherentes o consecuentes, es decir, que se manifiesten de acuerdo con los rasgos que los definen. Así, según Aristóteles, no es coherente el carácter de Ifigenia en la Ifigenia en Áulide, que aparece al principio llena de miedo, suplicando por su vida, y luego se comporta como una heroína dispuesta al sacrificio. Lesky, que no comparte el juicio de Aristóteles, piensa que aquí culminan la riqueza y la agilidad psíquica que se observa en algunas tragedias tardías de Eurípides: Ifigenia, al enterarse de que va a ser sacrificada, ruega por su vida con palabras conmovedoras dictadas por el deseo de seguir viviendo. Llega hasta la negación del principio fundamental de la ética aristocrática: «mejor es vivir en la ignominia -dice- que morir con honra», pero después, movida por las razones de su padre y por el peligro que amenaza a Aquiles, cambia de actitud y acepta su propia muerte para asegurar así la victoria de los aqueos. El motivo del sacrificio voluntario, frecuente en las obras de Eurípides, alcanza aquí su máximo efecto: representa la interpretación del proceso psíquico que lleva al ofrecimiento de la propia vida por una causa noble. Es, en definitiva, el drama de un ser joven que pasa del temor a la muerte y de una voluntad apasionada de seguir viviendo, a la aceptación consciente y serena del sacrificio. Ifigenia en Áulide, concluye Lesky (1937: 224-229), significa un poderoso avance en dirección al drama moderno. No es, a mi juicio, el mejor ejemplo de la brillante caracterización que ofrecen muchas tragedias de Eurípides: la mutación repentina del carácter de Ifigenia responde a razones un tanto zafias y patrioteras, difícilmente 
atribuibles a la complejidad psicológica del personaje, que no constituye, por lo demás, el asunto central de esta tragedia.

Poco, en realidad nada, dice Aristóteles de las tragedias éticas (18 $1456^{\mathrm{a}}$ ), pero Eurípides ofrece en su Hécuba un ejemplo que, si no me engaño, puede considerarse paradigmático de este tipo de tragedias. La importancia de la educación en la formación del carácter, del que Hécuba llega a decir que constituye el principio más sólido de la vida humana (vv. 593-605), se cuestiona aquí en relación con el nomos que regula los comportamientos individuales en el seno de la comunidad: el sacrificio voluntario de Polixena, que acepta la muerte con la dignidad y fortaleza que corresponde a su linaje, a su educación, se opone aquí al asesinato de Polidoro, el retoño indefenso confiado al cuidado de Poliméstor. La violación del principio de hospitalidad es para Hécuba el anuncio de algo nuevo, increíble e innombrable -Veo cosas increíbles, nuevas, nuevas [...] Cosas increíbles, sin nombre, más allá del prodigio, no piadosas ni tolerables (vv. 689; 714-715)-, de la crisis de los valores en los que se ha asentado la formación misma del carácter: la venganza se desata como retorno a lo primario, como degeneración, en sentido literal, porque se han quebrantado las normas básicas sobre las que se construye el sujeto en el seno de sus relaciones con la comunidad. A Polidoro se le ha arrebatado a traición la posibilidad misma de construir su carácter; Políxena ha aceptado la muerte con dignidad porque no ha llegado a cuestionarse el sentido de su sacrificio; Hécuba, la noble anciana, que ha perdido poder, libertad y familia, no podrá soportar ya la pérdida del sentido sobre el que se asentaban sus valores más firmes. 


\section{BIBLIOGRAFÍA}

Alamillo, Assela (1981): Sófocles. Tragedias, Madrid, Gredos, 1986.

Alsina, J. ed. (1977): Aristóteles. Poética, Barcelona, Bosch.

Apostle, G., Dobbs, E., y Parslow, M., eds. (1990): Aristotle’s Poetics, Iowa, Grinnel.

Araujo, M. y Julián Marías $\left(1989^{5}\right)$ : Ética a Nicómano, Madrid, Centro de Estudios Constitucionales.

Benedetto, V. y Medda, E. (1997): La tragedia sulla scena. La tragedia greca in quanto spettacolo teatrale, Torino, Einaudi.

Bobes, C. y otros (1995): Historia de la Teoría literaria. La Antigüedad grecolatina, Madrid, Gredos.

Bobes, C. (2001): Semiótica de la escena, Madrid, Arco/Libros.

Bobes, C. (2018): Elpersonaje literario en el relato, Madrid, Consejo Superior de Investigaciones Científicas.

Butcher, S.H. ed. (1951): Aristotle's theory of poetry and fine art, Nueva York, Dover.

Calvo Martínez, J.L (1978): Eurípides, Tragedias Madrid, Gredos. Traducción de J.L. Calvo

Martínez e introducción de Alberto Medina González y Juan Antonio López Pérez.

Capelleti, A.J., ed. (1990): Aristóteles Poética, Caracas, Monte Ávila.

Collingwood, R.G. (1938): Los principios del arte, México, Fondo de Cultura Económica, 1976.

Cooper, L. ed. (1947): Aristotle, on the art of poetry, Ithaca, Cornell University Press.

Cueto, M. (2007): «Los espacios del teatro», en El texto en el espacio, monográfico coordinado por J. A. Pérez Bowie, Las puertas del drama. Revista de la Asociación de Autores Dramáticos, Madrid: 4-10

Cueto, M. (2012): «Mundos dramáticos. Hacia una retórica de la autentificación ficcional», Castilla. Revista de Literatura, 3: 629-645.

Dodds, E.R. (1951): Los griegos y lo irracional, Madrid, Alianza Editorial, 1989.

Doležel, L. (1990): Historia breve de la Poética, Madrid, Síntesis, 1997.

Domini, P. (1999): «La tragedia senza la catarsi», Phronesis XLIII, I: 26-41.

Dupont-Roc, R., y Lallot, J., eds. (1980): La Poétique, Paris, Seuil.

Düring, I. (1987): Aristóteles. Exposición e interpretación de su pensamiento, México, UNAM.

Elsen. F.G., ed. (1957): Aristotle's Poetics the argument, Leiden, E.J. Brill.

García Bacca, J.D. (1943): Sobre estética griega, México, Imprenta Universitaria.

García Bacca, J.D. (1946): Poética, UNAM, 2000. 
García Berrio, A. (1977): Formación de la Teoría Literaria moderna I. La tópica horaciana en Europa, Madrid, Cupsa.

García Yebra, V. (1974): La Poética de Aristóteles, Madrid, Gredos.

Genette, G. (1979): Introduction a l'architexte, Paris, Seuil.

Girard, R. (1972): La violencia y lo sagrado, Barcelona, Anagrama, 1983.

Golden, L. (1976): «The clarification theory of katharsis», Hermes, 104: 437-452.

González Pérez, A. (1987): Aristóteles, Horacio, Boileau. Arte Poética, Madrid, Taurus.

Hegel, G.W.F. (1835): «De la poesía dramática en sus diversas especies y en su desenvolvimiento histórico», Estética II, Barcelona, Alta Fulla, 1988: 510-554.

Jaeger, W. (1933): Paideia: los ideales de la cultura griega, México, Fondo de Cultura Económica, 1983.

Janko, R. (1992), «From katharsis to the Aristotelian mean», en A. O. Rorty (ed.), Essays on Aristotle's Poetics, Nueva Jersey, Princeton University Press: 342-359.

Kommerell, M. (1984): Lessing y Aristóteles. Investigaciones acerca de la teoría de la tragedia, Madrid, Visor, 1990.

Lesky, A. (1937): La tragedia griega, Barcelona, Labor, 1973.

Llanos, A. (1980): Poética, Buenos Aires, Leviatán.

Lucas, D.W. (1968): Aristotle's Poetics, Oxford, University Press.

Marías, J. y Araujo, M. (1989): Aristóteles. Política, Madrid, Centro de Estudios Constitucionales.

Martínez, J.A. (1983): «Viejos y renovados perfiles de arte poética», Revista Española de Lingüistica, 2(3): 328-329.

Muguerza, J. (1977): La razón sin esperanza, Madrid, Consejo Superior de Investigaciones Científicas, 2009.

Nietzsche, F. (1871): El nacimiento de la tragedia, Madrid, Alianza, 1978.

Nussbaum, M.C. (1986): La fragilidad del bien. Fortuna y ética en la tragedia y la filosofía griega, Madrid, Visor, 1995.

Perea Morales, B. (1986): Esquilo. Tragedias, Madrid, Gredos.

Racionero, Q. (1990): Aristóteles. Retórica, Madrid, Gredos.

Ricoeur, P. (1983): Tiempo y narración, Madrid, Cristiandad.

Rodríguez Adrados, F. (1983): Fiesta, comedia y tragedia, Madrid, Alianza.

Romilly, J. de (1970): La tragédie grecque, Paris, Presses Universitaires de France, 1982.

Rorty, A.O. (ed.): Essays on Aristotle's Poetics, Nueva Jersey, Princeton University Press, 1992. 


\section{an}

üe Actio nova: ReVISTA de TeORÍA DE LA LITERATURA y LITERATURA COMPARADA, 5: $285-329$ DOI: https://doi.org/10.15366/actionova2021.5.013

Steiner, G. (1984): Antígonas, Barcelona, Gedisa, 1991.

Szondi, P. (1978): Teoría del drama moderno. Tentativa sobre lo trágico, Barcelona, Destino, 1994.

Trueba Atienza, C. (2002): Ética y tragedia en Aristóteles (2002), México, Anthropos/UNAM, 2004.

Vernant, J.P y Vidal Naquet, P. (1972): Mito y tragedia en la Grecia antigua I, Madrid, Taurus, 1987.

Villanueva, D. (2008): El Quijote antes del cinema, Madrid, Real Academia Española.

Weil, S. (1961): La fuente griega, Buenos Aires, Editorial Sudamericana. 
SOBRE LA AUTORA

\section{Magdalena Cueto Pérez}

Catedrática de Teoría de la literatura y literatura comparada de la Universidad de Oviedo.

Contact information: correo electrónico:magena@uniovi.es 